\title{
Generation of Deccan Trap magmas
}

\author{
Gautam SEN \\ Department of Earth Sciences and Florida Center for Analytical Electron Microscopy, Florida \\ International University, University Park, Miami, FL 33199.
}

Deccan Trap magmas may have erupted through multiple centers, the most prominent of which may have been a shield volcano-like structure in the Western Ghats area. The lavas are predominantly tholeiitic; alkalic mafic lavas and carbonatites are rare. Radioisotope dating, magnetic chronology, and age constraints from paleontology indicate that although the eruption started some $68 \mathrm{Ma}$, the bulk of lavas erupted at around 65-66 Ma. Paleomagnetic constraints indicate an uncertainty of $\pm 500,000$ years for peak volcanic activity at 65 m.y. in the type section of the Western Ghats. Maximum magma residence times were calculated in this study based on growth rates of "giant plagioclase" crystals in lavas that marked the end phase of volcanic activity of different magma chambers. These calculations suggest that the $>1.7 \mathrm{~km}$ thick Western Ghats section might have erupted within a much shorter time interval of $\sim 55,000$ years, implying phenomenal eruption rates that are orders of magnitude larger than any present-day eruption rate from any tectonic environment. Other significant observations/conclusions are as follows: (1) Deccan lavas can be grouped into stratigraphic subdivisions based on their geochemistry; (2) While some formations are relatively uncontaminated others are strongly contaminated by the continental crust; (3) Deccan magmas were produced by 15-30\% melting of a Fe-rich lherzolitic source at $\sim 3-2 \mathrm{GPa}$; (4) Parent magmas of the relatively uncontaminated Ambenali formation had a primitive composition with $16 \% \mathrm{MgO}, 47 \% \mathrm{SiO}_{2}$; (5) Deccan magmas were generated much deeper and by significantly more melting than other continental flood basalt provinces; (6) The erupted Deccan tholeiitic lavas underwent fractionation and magma mixing at $\sim 0.2 \mathrm{GPa}$. The composition and origin of the crust and crust/mantle boundary beneath the Deccan are discussed with respect to the influence of Deccan magmatic episode.

\section{Introduction}

"The close of the Mesozoic era was marked by the outpouring of enormous lava flows which spread over vast areas of Western, Central, and Southern India. They issued through long narrow fissures or cracks in the earth's crust, from a large magma basin and are therefore called fissure eruptions ..... The flows are called traps because of the step-like or terraced appearance of their outcrops, the term being of Scandinavian origin."

-M. S. Krishnan ("Geology of India and Burma" 1982)
Today, the Deccan Traps volcanic province (Figure 1) has emerged as one of the most interesting subjects of research for two principal reasonsits enormous size and eruption at the $\mathrm{K} / \mathrm{T}$ boundary. The predominantly tholeiitic lavas of the Deccan appear to have erupted some $65( \pm 4)$ m.y. ago when the Indian continent was rapidly migrating northward (e.g., Chatterjee and Rudra 1992; figure 2). There are several other voluminous basalt provinces on Earth like the Deccan, such as the Paraña basalts of South America, Siberian Traps (Russia), Karoo (Africa), Columbia River Basalts (North America), Caribbean Sea-floor basalts, and the Ontong Java plateau (western Pacific Ocean).

Keywords. Deccan Trap; giant Plagioclase basalt; age; contamination; fractional crystallization; magma generation. 


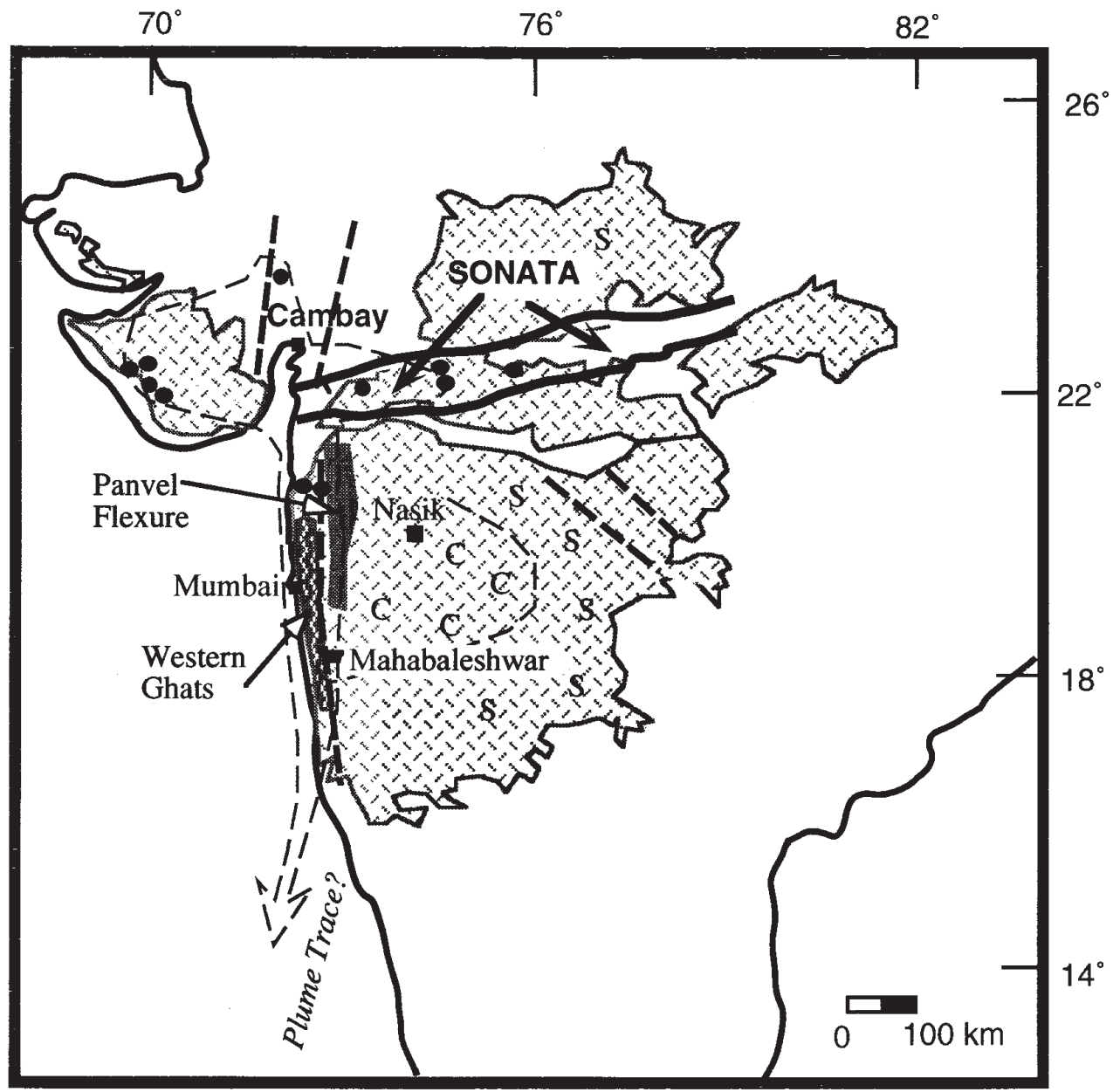

$\mathrm{C}=$ Compound Flow (mostly pa hoe hoe)
$\mathrm{S}=$ Simple Flow (mostly aa)

Figure 1. Map showing distribution of Deccan Trap lavas and important rift systems. The dots represent alkalic/carbonatite occurrences. The distribution map of simple and compound flows is from Walker (1999). The plume trace (dashed with arrow) is thought to hug the western coast of India however, its form near the Cambay triple junction is unclear.

Such predominantly basaltic provinces have also been called "flood basalts", "plateau basalts", and "large igneous provinces". In spite of the Deccan's obvious appeal, systematic studies of this province did not begin until the 1980s. Two exceptions to this statement are the works of West (1958) and Sukheswala and Poldervaart (1958). The reader is encouraged to peruse Mahoney's (1988) outstanding review of Deccan research up to about 1986 for important background information during that period.

The period from 1980 to early 1990s saw a sudden burst of research activity on the Deccan, starting with the publication of a few critical papers. Although stated as a "personal perspective", the recently published review article by Hooper (1999) is a must read for all Deccan geochemists because it relates current issues to pre-1980 research. Hooper addresses a range of topics, from stratigraphic correlation, migration of the source of the magmas, to feeder systems and the relationship between tectonic extension, uplift and subsidence, magma eruption, and morphologic development of the Western Ghats. Another interesting read is Cox's (1999) paper in which he focused on the role played by Deccan research in the "picrite" vs. "tholeiite" primary magma controversy.

In this author's view, the stage for systematic studies (1980s onward) of the Deccan was set by a detailed petrographic study by Deshmukh et al (1977) of two Western Ghats sections, particularly the famous Mahabaleshwar section $(1.2 \mathrm{~km}$ thick), where the authors identified 42 lava flows. This was followed by a geochemical study by Najafi et al (1981) of the lava flows of the Mahad-Mahabaleshwar section. An Nd, Sr isotopic study by Mahoney et al (1982) of the Mahabaleshwar section quickly followed and demonstrated that flood basalts are not characterized by monotonous chemistry. They showed that strongly contaminated lavas and virtually uncontaminated lavas occur in the same section of the Western Ghats. Mahoney et al (1982) also showed that the most contaminated (e.g., high ${ }^{87} \mathrm{Sr} /{ }^{86} \mathrm{Sr}$ ratio) 


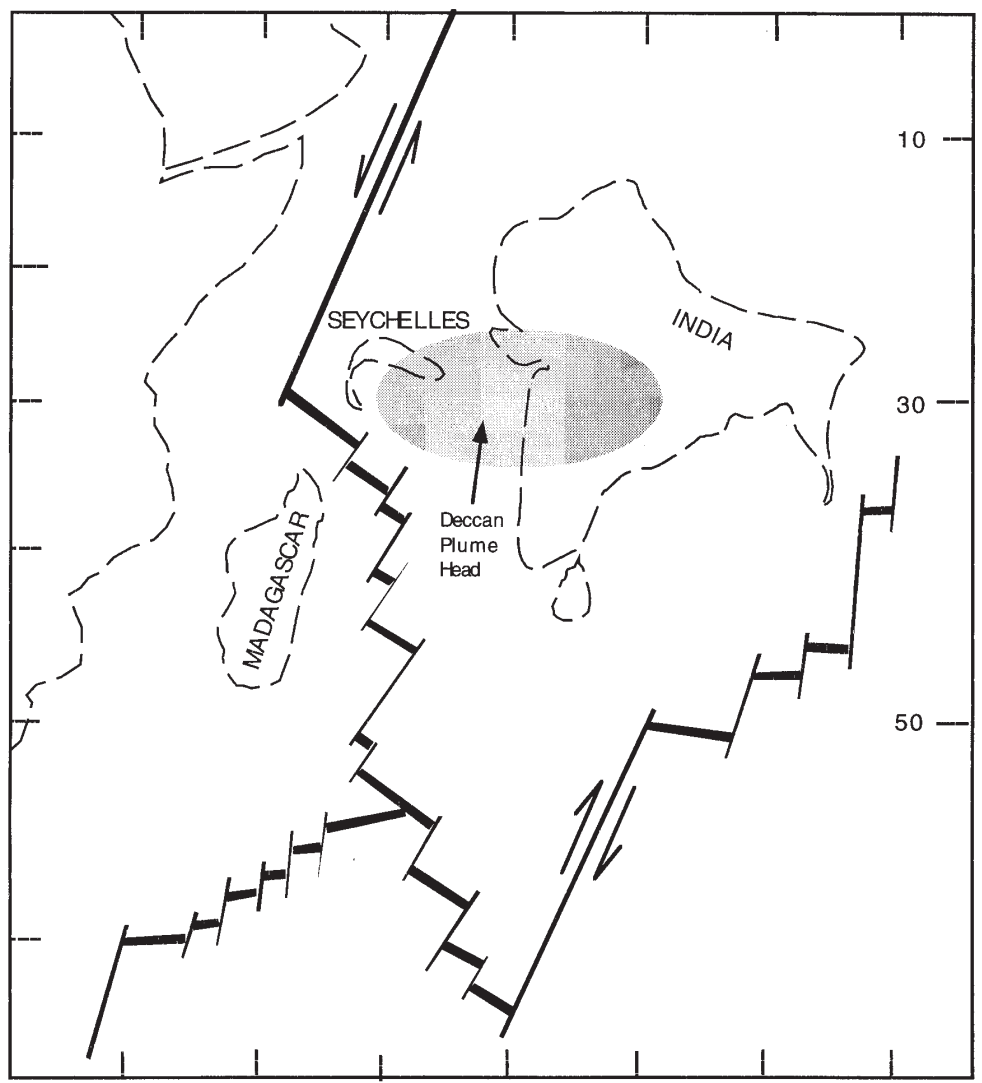

Figure 2. Paleo-location of India with reference to the plume head (after Duncan and Richards 1991).

lava samples were also the least differentiated (e.g., higher $\mathrm{Mg} \#)$ - a feature that would seem to go against common intuition! Their finding was timely because at the same time Watson (1982) published a paper detailing how basalt magmas passing through the continental crust might selectively pick up some elements from the surrounding crust while disposing of others. Based on this study, Mahoney et al.'s finding would appear to be a good example of the process of selective contamination. Sen (1986) presented a mineralogical synthesis of the Mahoney et al samples in a follow-up publication and concluded that open-system fractionation and magma mixing processes in shallow, crustal magma chambers were a controlling factor in determining the major and trace element chemistry of Deccan lavas.

Cox and Hawkesworth (1985) and Beane et al (1986) made a significant leap in Deccan lava geochemistry. They presented "geochemical stratigraphy" of the lavas of the Western Ghats, elucidating details of elemental and isotopic variations. Beane et al provided additional information on the petrography of the samples. Formal lithostratigraphic nomenclature was used to classify the Western Ghats lavas into three subgroups, and several formations were assigned to each subgroup (table 1). It became apparent that lava geochemistry can be used as a tool to carry out spa- tial correlation between distant areas of the Deccan. This in turn may help resolve such important issues as the relative volumes of the various lava formations in the Deccan, lateral extent of individual flows, extent of involvement of the continental crust, location of major eruption centers, etc. As far as the Deccan is concerned, this new approach changed the way this lava province was viewed.

Mahoney et al (1985) carried out an isotopic investigation of some alkalic and tholeiitic basaltic lavas in the northern Deccan area along the Narmada River. These lavas are essentially contemporaneous because they alternate in the same field section. Mahoney et al determined that the alkalic and tholeiitic lavas have similar isotopic composition and are roughly equal in volume in that particular Narmada section. Although it has long been known that the Deccan Trap lavas are predominantly tholeiitic, Mahoney et al justifiably wondered whether other unexplored areas of the Deccan might be found where alkalic basalts occur in significant volumes.

Alkalic basalts, nephelinites, basanites, picrites, and carbonatites do occur along the peripheral regions of the Deccan (figure 1; e.g., Bose 1980). They all occur along three prominent tectonic areas that have received much attention: the east-west trending "SONATA" region, which is a rift sys- 
Table 1. Deccan Trap lava Formations of the Western Ghats.

\begin{tabular}{lllll}
\hline Subgroup & Formation & $\begin{array}{l}\text { Thickness } \\
(\mathrm{m})\end{array}$ & Phenocrysts & $\begin{array}{l}\mathrm{MgO} \\
\text { Range }\end{array}$ \\
\hline \multirow{6}{*}{ Wai } & Desur & & $\mathrm{Ol}+\mathrm{Pl}$ & $5-6$ \\
& Panhala & $(>150)$ & $\mathrm{Ol}+\mathrm{Pl}$ & $6.3-6.8$ \\
& Mahabaleshwar & $(280)$ & $\mathrm{Ol}+\mathrm{Pl}$ & $5-6.7$ \\
& Ambenali & $(500)$ & $\mathrm{Ol}+\mathrm{Pl}$ & $5-7$ \\
& Poladpur & $(370)$ & $\mathrm{Ol}+\mathrm{Pl}$ & $6-9$ \\
\hline \multirow{2}{*}{ Lonavala } & Bushe & $(325)$ & $\mathrm{Ol}+\mathrm{Pl}+\mathrm{Aug}$ & $5-12$ \\
& Khandala & $(140)$ & $\mathrm{Ol}+\mathrm{Pl}+\mathrm{Aug}$ & $4.2-9.4$ \\
\hline \multirow{6}{*}{ Kalsubai } & Bhimashankar & $(140)$ & $\mathrm{Ol}$ & $5-6.5$ \\
& Thakurvadi & $(400)$ & $\mathrm{Ol}+[\mathrm{Pl}]+\mathrm{Aug}$ & $5-10$ \\
& Neral & $(100)$ & $\mathrm{Ol}+\mathrm{Pl}$ & $5-11$ \\
& Igatpuri & $(150)$ & $\mathrm{Ol}+\mathrm{Pl}$ & $5-10$ \\
& Jawahar & $(>200)$ & $\mathrm{Ol}+\mathrm{Pl}$ & $5-10$ \\
\hline
\end{tabular}

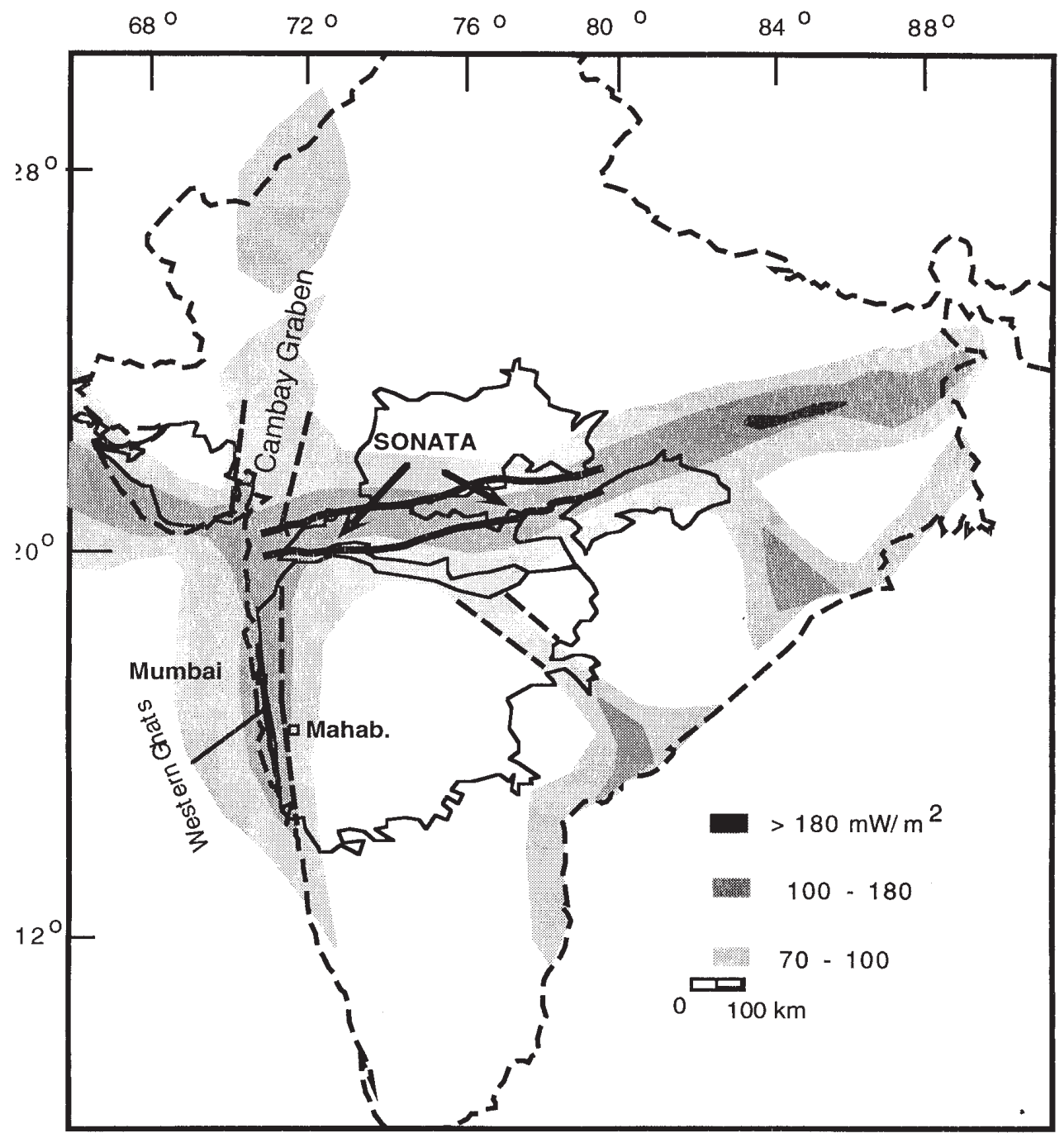

Figure 3. A generalized heat flow map of the Indian peninsula (modified from Ravi Shanker 1988). 


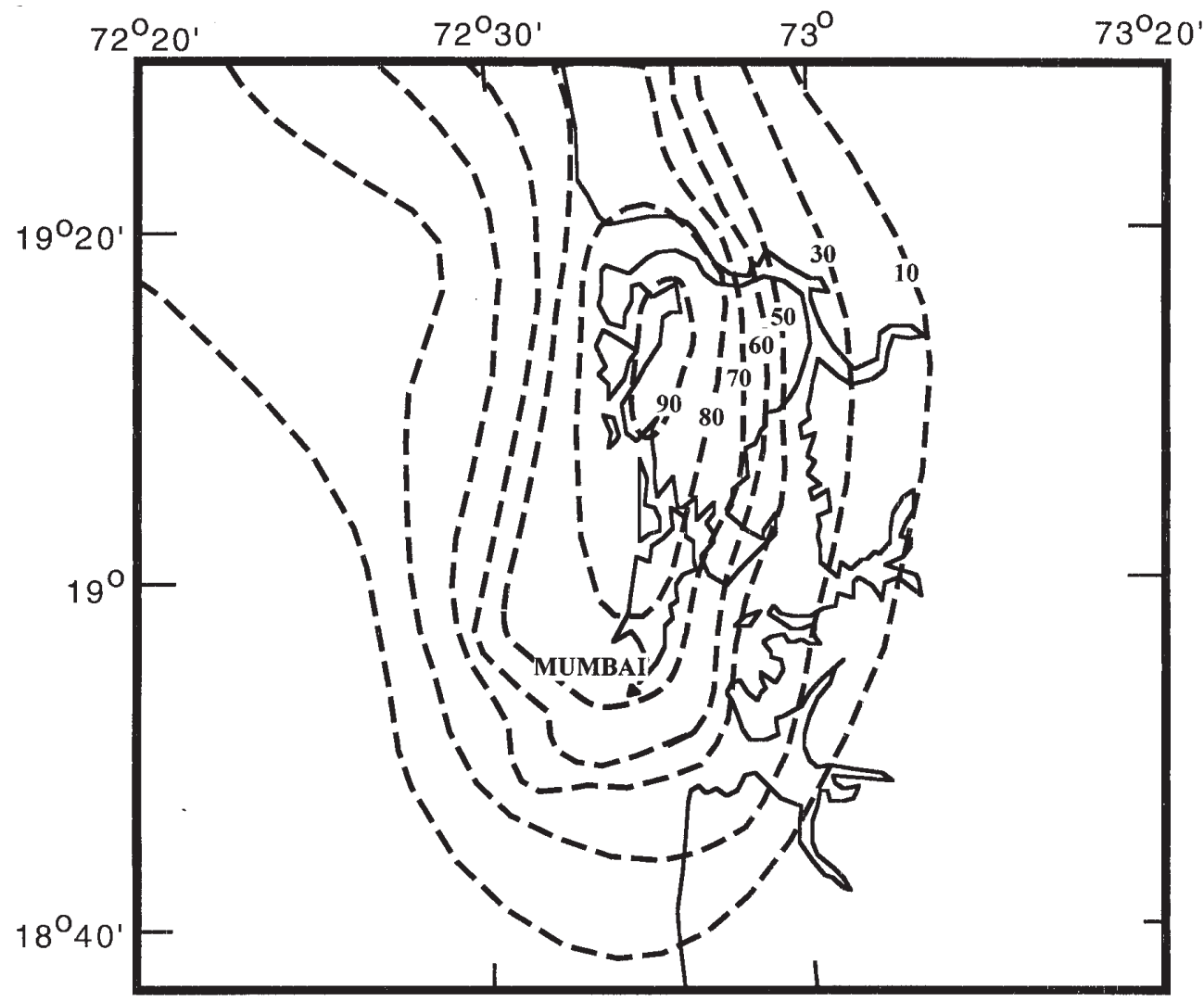

Figure 4. Gravity map around Mumbai (from Takin 1966). The numbers are in milligals.

tem that has undergone many episodes of activation, the Cambay rift system in the northwest, and the Panvel Flexure to the west of the Western Ghats (figure 1). These regions are also characterized by high heat flow and a concentration of dikes (Figure 3). Based on recent ${ }^{40} \mathrm{Ar}^{39}{ }^{39} \mathrm{Ar}$ dates it appears that some alkalic lavas (68-69 m.y.) in the northwest Deccan predate the tholeiites (6566 m.y.) (Basu et al 1993). On the other hand, other alkalic lavas along the Narmada rift and in the southern areas are contemporaneous with or are younger than the predominantly tholeiitic lavas (e.g., Basu et al 1993; Gwalani et al 1993, 1995; Simonetti et al 1995; Ray et al 2000).

Mildly alkaline as well as tholeiitic dikes trending roughly in a N-S direction occur on the western side (Panvel Flexure) of the Western Ghats. The specific rock types include trachyte, rhyolite, lamprophyre, nepheline syenite, basanite, and ijolite (e.g., Sethna and Mousavi 1994). Some of these dikes carry mantle xenoliths of garnet pyroxenites and spinel lherzolites (Dessai and Vaselli 1999 and personal communication). These 60-61 m.y. old dikes are believed to be related to the E-W extension that produced an off-shore gravity high (Bombay High: figure 4) and N-S grabens (Hooper 1999). Hooper believes that this younger extension and magmatic episode, which postdate the peak tholeiitic eruption, was probably related to the splitting of the Seychelles platform from the Indian plate. Carbonatites, alkaline magmas, and the tholeiites are thus all temporally and spatially part of a big picture that likely involves the Deccan plume, plume-lithosphere interaction, continental rifting, and magma generation. It is now clear that any model of Deccan tholeiite petrogenesis must have a satisfactory explanation for the generation of all of these magmas and not just the tholeiites (e.g., Basu et al 1993; Sen 1995).

While great strides were being made on Deccan lava geochemistry, important laboratory "analog" experiments relevant to the behavior of mantle plumes were being conducted in a few laboratories, particularly that of Ross Griffiths in the Australian National University. Questions pertaining to the origin of flood basalts, relationship between hot spot chains (such as the Hawaiian-Emperor chain) and mantle plumes, and the depth of origin and migration of plumes now took center stage. We learned that a plume, generated at the core/mantle boundary, may rise to shallow mantle while developing a large head and a long, narrow tail (figure 5: Richards et al 1989; Griffiths and Campbell 1990, 1991a,b; Campbell and Griffiths 1990). Richards et al proposed that flood basalts are generated over a relatively short period via melting of the plume head, whereas the plume tail may persist for millions of years and produce a hot-spot 


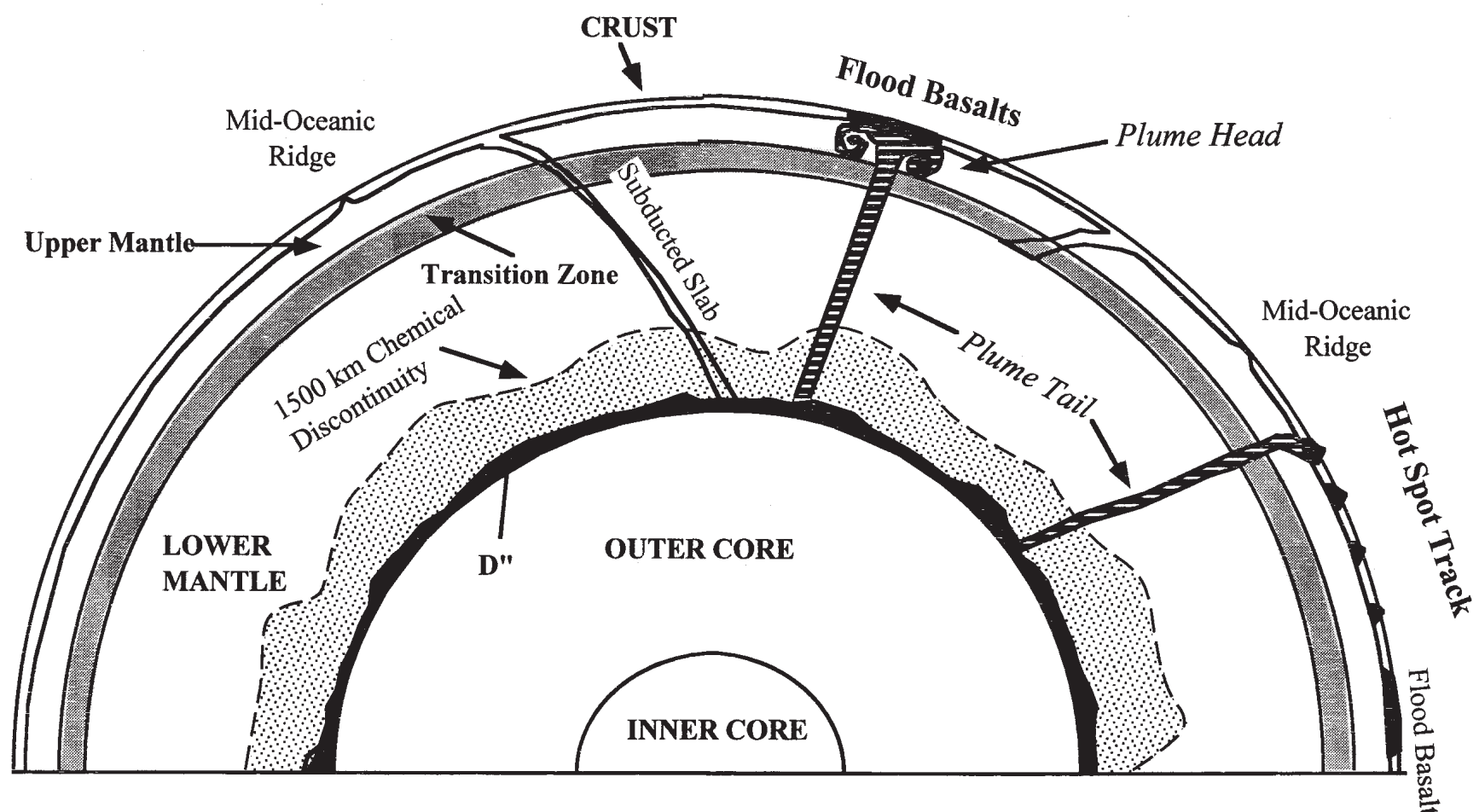

Figure 5. A global scale model showing the origin of large plumes from near the Core/Mantle boundary. The large plume heads melt and produce flood basalts whereas their tails persist for millions of years and generate hot spot tracks (source refs. in: Sen 2001).

track, such as the Hawaiian islands, on migrating lithosphere. In the Deccan case, it was shown through dating of the rocks that a hot spot track extends from the Deccan to the Chagos-Laccadive (or Lakkhadeep) and Rèunion islands (Duncan and Richards 1991). Presently, the hot spot that is believed to have once fed Deccan lavas is still producing lavas on the Rèunion island.

There is considerable debate about whether plumes rise from the core-mantle boundary or from the transition zone, or from a recently proposed chemical boundary layer often referred to as the 1500-km discontinuity (Kellogg et al 1999). Furthermore, even the plume theory for the origin of the Deccan has been questioned (e.g., Sheth 1999; discussed later). It is beyond the scope of this paper to review such matters in extensive detail.

The objectives of the present article are two: acquaint the reader with some overall background concepts about the Deccan and bring up some new issues about the Traps. The emphasis is on geochemistry and petrology because the bulk of the work has been done in these fields. It is beyond the scope of this review to address the significance of the fossils that have been found in ash (?) beds ("intertrappeans") that occur between lava flows in some areas (e.g., Krishnan 1982). In the end I summarize what we think we "know" about the Deccan.

\section{Some general features}

\subsection{Spatial variation in thickness and sources of eruption}

The Deccan Trap lava pile is the thickest in the western part of the province, reaching an exposed thickness of about $1.7 \mathrm{~km}$ in parts of the Western Ghats. It is the thinnest in the east, reaching no more than about $100 \mathrm{~m}$. As reflected in the above quotation from Krishnan (1982), most authors prior to about 1980 believed that Deccan lavas erupted through fissures or large cracks in the crust. In recent years, some authors have proposed that a major center of eruption was located near Nasik in the Western Ghats because of the following reasons:

- The lava pile is the thickest here.

- A rough mapping of the simple and compound flows shows that the latter are concentrated in the southwestern Deccan, whereas the former are found in the eastern and northern parts (Walker 1999). By comparison with Hawaiian and Columbia River basalt lava flows, it appears that compound structures are formed in lava piles that are very thick, which in turn is related to the proximity of source.

- Although the lava flows are essentially flatlying, a broad shield-volcano-like structure has been identified in the Western Ghats (figure 6; 


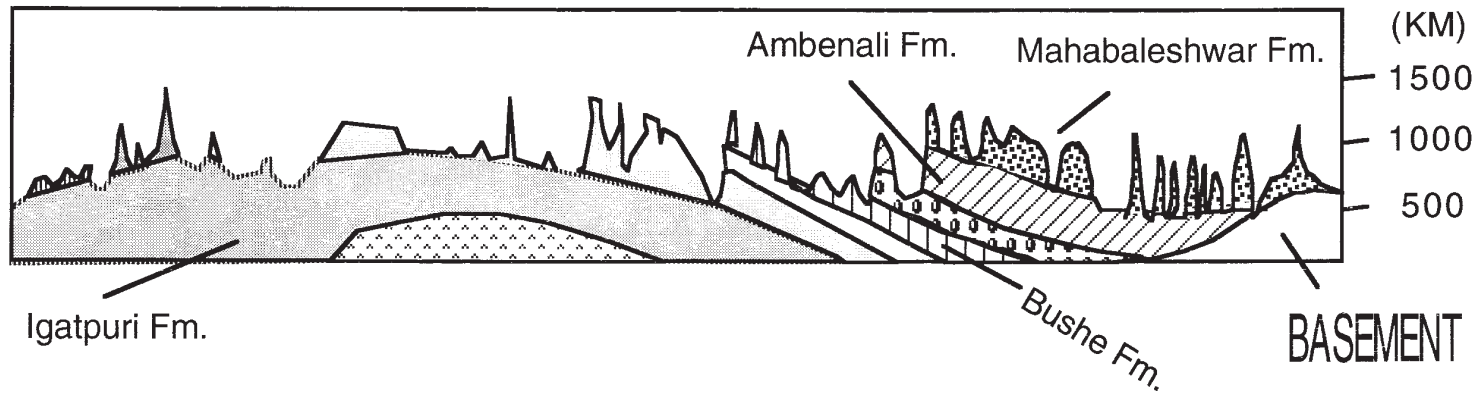

Figure 6. The shield volcano type structure along a north-south section through the Western Ghats ridge (from Belgaum in the south to Kondaibar in the north: after Subbarao et al 1994). Some prominent formations are shown.

cf. Beane et al 1986; Widdowson and Mitchell 1999). Based on the small dips $\left(1^{\bullet}\right)$ of various lava formations, Watts and Cox (1989) inferred that this structure formed due to lithospheric flexure caused by the "load" (crust added by the volcano, which was migrating southward). Widdowson and Mitchell (1999) suggest that the Western Ghats escarpment and the Panvel Flexure resulted from erosion of the load that was uplifted as a result of isostatic rebound.

Aside from this major volcanic edifice, a second locus of extrusion has been described from the Satpura area of Madhya Pradesh, where feeder intrusions can be linked to overlying lavas (cf. Crookshank 1936; Sen and Cohen 1994; Bhattacharji et al 1994). This was also substantiated by the seismic finding of a locally thick $(900 \mathrm{~m})$ basalt sequence near Jabalpur (Kaila 1988). There are other minor eruptive sites, particularly of alkalic magmas, that occur in the northwestern Deccan. These lavas have very distinct isotopic, major and trace element composition compared to those from southwestern Deccan (Krishnamurthy and Cox 1977; Melluso et al 1995; Peng and Mahoney 1995).

\subsection{Spatial extent of lava formations}

Stratigraphic correlation of the lava formations has been done for the southwestern and southeastern Deccan. A map showing the distribution of the formations in these areas has been published (Subbarao and Hooper 1988). Although geochemical data are also available for the northern, northeastern, and northwestern parts of the province, detailed correlation work has not been done. Major similarities and differences between the lavas of the Western Ghats and the eastern areas have been documented (see comments by Hooper 1999 and Mahoney et al 2000). Hooper (1999) pointed out the difficulty in using geochemistry as a longdistance correlation tool, noting that lavas of similar chemistry can erupt at two different sites at two different times. With this limitation in mind, one can still explore which chemically defined class or "magma type" is spatially most abundant, regardless of its position in a vertical sequence in any particular site. For example, in the CRB, the most abundant type is the Grande Rhonde formation. In the Deccan case, Poladpur-type lavas seem to be laterally most extensive, reaching some $800 \mathrm{~km}$ away from the Western Ghats (Mahoney et al 2000). At the other extreme, the Bushe formation appears to be rather "spotty" (Subbarao and Hooper 1988).

Post-Deccan faulting has made flow-by-flow correlation across major fault systems very difficult. For example, a well known and puzzling lack of correlation exists across the SONATA lineament, which has led to a suggestion of possible post-Deccan left-lateral strike-slip faulting of 200$400 \mathrm{~km}$ along the SONATA lineament (Mahoney 1988; Hooper 1999). Post-Deccan faulting and earthquakes still continue in the Deccan province, the most recent events being the Killari earthquake of 1993 and the Bhuj earthquake of 2001. These earthquakes occur principally in two belts - the SONATA and along a southwest coastal belt that essentially marks the hot spot trace (Mahadevan and Subbarao 1999).

On the basis of isotopic and trace element similarities and dissimilarities, several authors have noted that geochemical equivalents of the Thakurvadi, Khandala, Poladpur, Ambenali, and Mahabaleshwar formations extend far to the east and northeast (Mitchell and Widdowson 1991; Baksi 1994; Sen and Cohen 1994; Peng et al 1998; Khadri et al 1999; Mahoney et al 2000). Mahoney et al (2000) suggested that Poladpur formation-type lavas may be spatially the most extensive of all. Peng et al (1998) noted that Poladpur-like lavas of the northeastern Deccan are higher in ${ }^{206} \mathrm{~Pb} /{ }^{204} \mathrm{~Pb}$ than the Poladpur formation-type lavas of the Western Ghats, although they are similar in both $\mathrm{Nd}$ and $\mathrm{Sr}$ isotopic compositions. These authors interpreted this dissimilarity to mean 
that the northeastern lavas and the southwestern lavas of the same formation used very different feeder systems, as a result of which northeastern lavas underwent less crustal contamination.

\subsection{Volume of the Deccan}

Most articles on the Deccan Traps begin with an attempt to impress the reader how voluminous this lava province really is. However, a great deal of inconsistency between various authors in the reported volume is apparent (table 2). Also, it is not always clear whether the authors were intending to mean the erupted volume (i.e., volume of lava originally erupted) or the presently exposed volume, which would be less than the original erupted volume as some of the lavas would have been lost via erosion. It is likely that some melt was lost via crystallization in the crust and/or mantle, and thus the erupted volume (as well as the presently exposed volume) of lava is less than the actual volume of melt generated at the source region. Furthermore, some of the lavas either erupted on the ocean floor adjacent to the Western Ghats or became submarine as a result of post-rift subsidence and perhaps large landslides. Therefore, it is advisable to know the volume of Deccan lavas that are buried under off-shore sediments. In the future MCS (multi-channel seismometers) may be used to detect seaward dipping reflectors, which would be Deccan-related (J. Mahoney, pers. Comm., 2001).

The volume estimated from the exposed area and thickness of the lava province can only be considered as an apparent volume. The estimation of the apparent volume is far from easy, and a good estimate must be based on a clear knowledge of the "basement" topography; i.e., the topography of the surface on which the Deccan lavas erupted. While we have some understanding of the nature of that surface, significant 3-D details are lacking (cf. Ravi Shanker 1988). Our knowledge is primarily based on gravity and seismic measurements along a few transects or on a broad scale of coverage.

The question is what is more important - apparent volume or the actual volume of melt generated in understanding the Deccan volcanic episode? The answer will depend on who is seeking what: if one is interested in post-Deccan uplift of the Indian subcontinent and the erosion of the lava pile then he/she would be interested in both the erupted volume and present volume estimates (and of course, time). On the other hand, if for example the purpose is to understand how the Deccan magmatic episode may have affected the lower crust and upper mantle beneath the Indian subcontinent, then of course, the interest will be in the volume magma generated. It is with the above background that table 2 is presented, in which some volume and/or area estimates by previous authors are listed. The numbers clearly vary considerably. Considering the fact that a significant portion of the lava pile has probably been eroded, an erupted volume of about $3 \times 10^{6} \mathrm{~km}^{3}$ is probably a fairly conservative estimate. This estimate is based on an average thickness of $1 \mathrm{~km}$ and an originally erupted area of $2 \times 10^{6} \mathrm{~km}^{2}$ (Hooper 1999).

\subsection{Age and rate}

Much has been written already about the timing of Deccan lava eruption. Briefly, one would be correct to say that the "bulk" (95\%) of the lava erupted some 65-66 $( \pm 2)$ m.y. ago (figure 7; e.g., Courtillot et al 1986, Duncan and Pyle 1988; Venkatesan et al 1993; Baksi 1994, Allegre et al 1999). The lavas span only three magnetic chrons, 30N-29R-29N, with the bulk erupting at 29R (figure 7 ). Somewhat alkalic and carbonatitic lavas, believed to be related to the dominantly tholeiitic lavas, erupted both before and after the main tholeiitic episode (Basu et al 1993). Including these, it would be safe to say that the total eruption of Deccan lavas occurred from 68.5 to $64 \mathrm{Ma}$

The volumetric rate at which these lavas erupted is an unresolved question. Part of the problem is that no existing dating method can be employed to obtain dates that can distinguish between $\sim 65$ m.y. old lavas whose eruptions were separated by only a few thousand years. Those authors (e.g., McLean 1985) interested in the short-term (on 10100 year time scales) impact of the Deccan eruption on mass extinction and climatic events have therefore been frustrated by the limitations of dating methods. Application of the magnetic polarity time scale and evaluation of the radioisotope dates vis-à-vis the magnetic time scale led Courtillot et al (1986) to the conclusion that the "average extrusion rates could have been in excess of $1 \mathrm{~km}^{3}$ per year". This could very well be the case, which is also implied by the general lack of significant erosional features between lava flows (e.g., West 1981). Courtillot et al pointed out that this is a very high rate when compared with Hawaii $\left(0.1 \mathrm{~km}^{3}\right.$ per year). Even if we accept their analysis of what the various magnetic chrons in the Deccan mean, we still have the uncertainty of the true erupted volume, and hence the actual rate remains uncertain. Also, the rate as stated is a mean rate; and in reality it is likely that even within the geologically 
Table 2. Some published estimates of volume/area of Deccan Traps.

\begin{tabular}{|c|c|c|c|}
\hline Author(s) & Year & Volume & Area \\
\hline P R Hooper & 1999 & & 1-2 million $\mathrm{km}^{2}$ (erupted) \\
\hline Coffin \& Eldholm & 1993 & 9 million $\mathrm{km}^{3}$ & 1.8 million $\mathrm{km}^{2}$ (erupted) \\
\hline A B Watts \& K G Cox & 1989 & & $800,000 \mathrm{~km}^{2}$ (present coverage) \\
\hline W D West & 1983 & "probably" > 250,000 km³ (erupted) & \\
\hline S S Deshmukh & 1982 & $>10$ million $\mathrm{km}^{3}$ (erupted) & \\
\hline K V Subbarao \& R N Sukheswala & 1981 & & $500,000 \mathrm{~km}^{2}$ (present coverage) \\
\hline E H Pascoe & 1964 & & $>2.6$ million $\mathrm{km}^{2}$ (erupted) \\
\hline
\end{tabular}

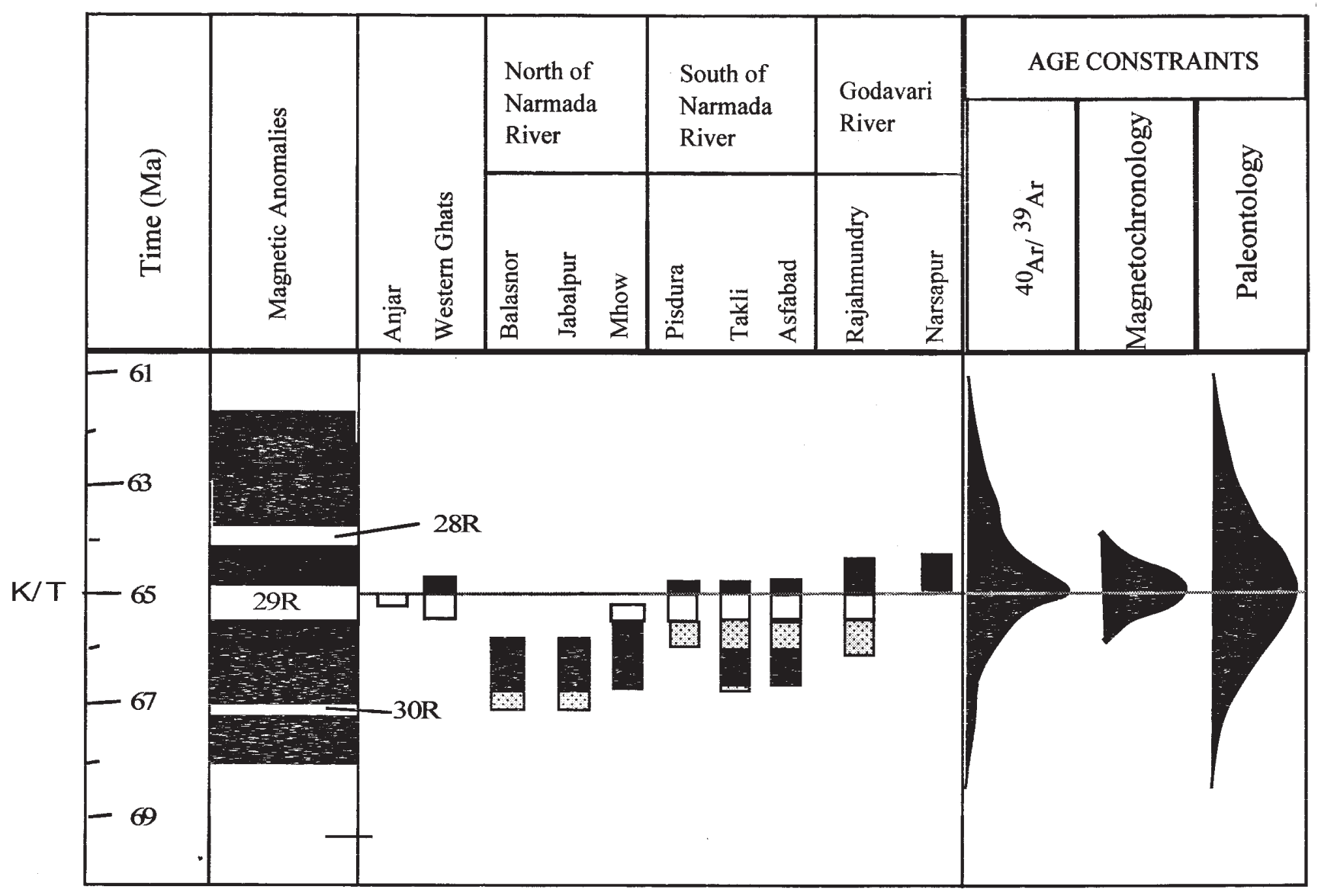

Figure 7. Summary plot of age determinations of the Deccan Traps. (from Chatterjee and Rudra 1992).

short interval within which these lavas erupted, the true rate was highly variable.

\section{Petrography}

Olivine, augite, and plagioclase phenocrysts are common in the tholeiitic lavas. Titanimagnetite, ilmenite, and sulfides occur as groundmass. Olivine has been found to occur in the groundmass in some rare cases, mostly in intrusives. Olivine is commonly altered to iddingsitic material, and such olivine pseudomorphs can only be recognized when the original euhedral shape is preserved. The average modal content of (total) phenocrysts in the Western Ghats lavas is around 10-12\% (Sen 1986, Devey and Cox 1987). The actual phenocryst content varies rather widely, however. Noting that Poladpur, Ambenali, and Mahabaleshwar formation lavas have similar mean total phenocryst contents, Devey and Cox suggested that this meant that the flow rates of these lavas from their source magma chambers were similar. Of course, this is a very simplistic interpretation because total phenocryst content depends upon nucleation and growth rates, bulk composition (i.e., proximity to 
the saturation curve for a given phase) of the magma, and magma residence time in subcrustal chambers. A thorough CSD (crystal size distribution) study is needed in order to address some of the kinetic issues related to phenocryst growth and abundance.

3.1 A new estimate of average Deccan eruption rate from red boles and giant phenocryst basalts $(G P B)$

In contrast to all prior publications, I adopt a very different "back-of-the-envelope" approach, based on phenocryst growth rates, to address the issue of magma residence times in Deccan magma chambers. Figure 3 shows the "average" phenocrysts present in each formation (Data sources: mainly Deshmukh et al 1977; supplementary information from Beane 1988, Sen 1986). Note that within each formation a number of flows occur, some of which may be free of phenocrysts, others carry all three $(\mathrm{ol}+\mathrm{pl}+\mathrm{cpx})$ phenocrysts, and still others may have a single phenocryst phase. The modes also vary tremendously between and within individual flows, which is well-documented in J Beane's (1988) dissertation. Phenocryst accumulation, particularly of olivine, has demonstrably occurred near the base of some flows (Beane and Hooper 1988). This accumulation is often local in nature, making the lava flows locally picritic. This is particularly true of the flows in the lower formations, as reflected in the large range of $\mathrm{MgO}$ values cited in figure 3 .

Lava flows, termed "giant phenocryst basalt" (GPB), characterized by plagioclase megacrysts ( $\sim 2-10 \mathrm{~cm}$ long), occur within each formation (Hooper et al 1988; Pankov et al 1994) and are of particular relevance in this study. GPBs are generally highly fractionated (low $\mathrm{MgO}$ ) lavas and yet their plagioclase megacrysts $\left(\mathrm{An}_{61-64}\right)$ have similar or greater anorthite content than in higher- $\mathrm{MgO}$ lavas in which plagioclase does not form a distinct phenocryst (cf. Sen 1986; Beane 1988; Pankov et al 1994).

Pankov et al (1994) made a detailed study of the plagioclase phenocrysts in three GPBs from the Khandala, Jawhar, and Thakurvadi formations of the Kalsubai subgroup (Western Ghats). Plagioclase crystals in the three samples they examined generally exhibit normal zoning with

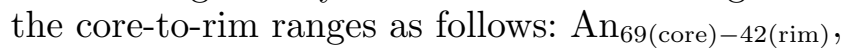

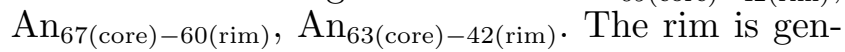
erally no thicker than $\sim 0.5 \mathrm{~mm}$. Pankov et al. (1994, p. 190) pointed out the presence of reverse zoning of $\sim 20 \mu \mathrm{m}$ width in the inner parts of some plagioclase crystals; and that there are mineral and melt inclusions that are evenly distributed within individual plagioclase phenocrysts. Extremely Ferich olivines $\left(\mathrm{FO}_{32-40}\right)$ were found to occur near the rims of these plagioclase crystals. Both augite and pigeonite were found to be included in these plagioclase crystals, with both pyroxenes becoming more Fe-rich from the core to rim of the host plagioclase crystals. Pankov et al (1994) also noted the occurrence of an extremely Fe-rich subcalcic ferroaugite type pyroxenes near the edge of the plagioclase phenocrysts. These Fe-rich pyroxenes apparently formed as quench crystals from extremely differentiated, Fe-rich, interstitial liquid.

A straightforward interpretation of the above observations is that the GPBs represent flows in which the phenocrysts accumulated by flotation in highly differentiated (therefore, denser than plagioclase) magmas that concentrated near the roofs of magma chambers. During a period of magmachamber dormancy such plagioclase crystals grew to large sizes. Finally, a GPB eruption occurred, perhaps due to magma chamber collapse or fresh input of magma. Thus, each GPB eruption represents the culmination of an eruptive cycle of a magma chamber.

Figure 8 shows a distribution of phenocrysts in the Western Ghats lava sequence and the horizons at which GPBs occur (Deshmukh et al 1977). In addition, Beane (1988) identified at least two more GPBs. It is not possible at this time to determine where the Formation boundaries are located in this figure from Deshmukh et al's description. Although Beane (1988) suggests that GPB flows do not occur in the Wai Subgroup, this claim is disputed by D. Chandrasekharam (2001, pers. Comm.). An inspection of the data presented in Deshmukh et al (1977) suggests that at least the uppermost GPB occurs within the Wai subgroup. However, even if we accept Bean's conclusion that GPBs do not occur in the Wai subgroup, then it is possible that the eruptions were so rapid during the Wai stage that no magma batch managed to reside in its chamber long enough to form the giant plagioclase phenocrysts.

Figure 8 also shows the locations of "red bole" or red clay-rich horizons. A review of previous papers suggests that there are two fundamentally different interpretations of such horizons (e.g., Hooper et al 1988; Wilkins et al 1994; Inamdar and Kumar 1994; Inamdar 1995, Gupte 1995). One interpretation is that they are in situ or transported clay-rich (soil) horizons that may have formed by oxidation of the lava flows. Alternatively, they represent altered (lateritized) pyroclastic material (Wilkins et al 1994). Figure 8 shows that red bole horizons are commonly associated with GPBs, with the GPBs (and coarse-grained lava flows) often erupting on a red bole horizon. Note that this association was corroborated by recent preliminary field studies conducted by D. Chandrasekharam (2000, pers.comm.) This observation leads me to 


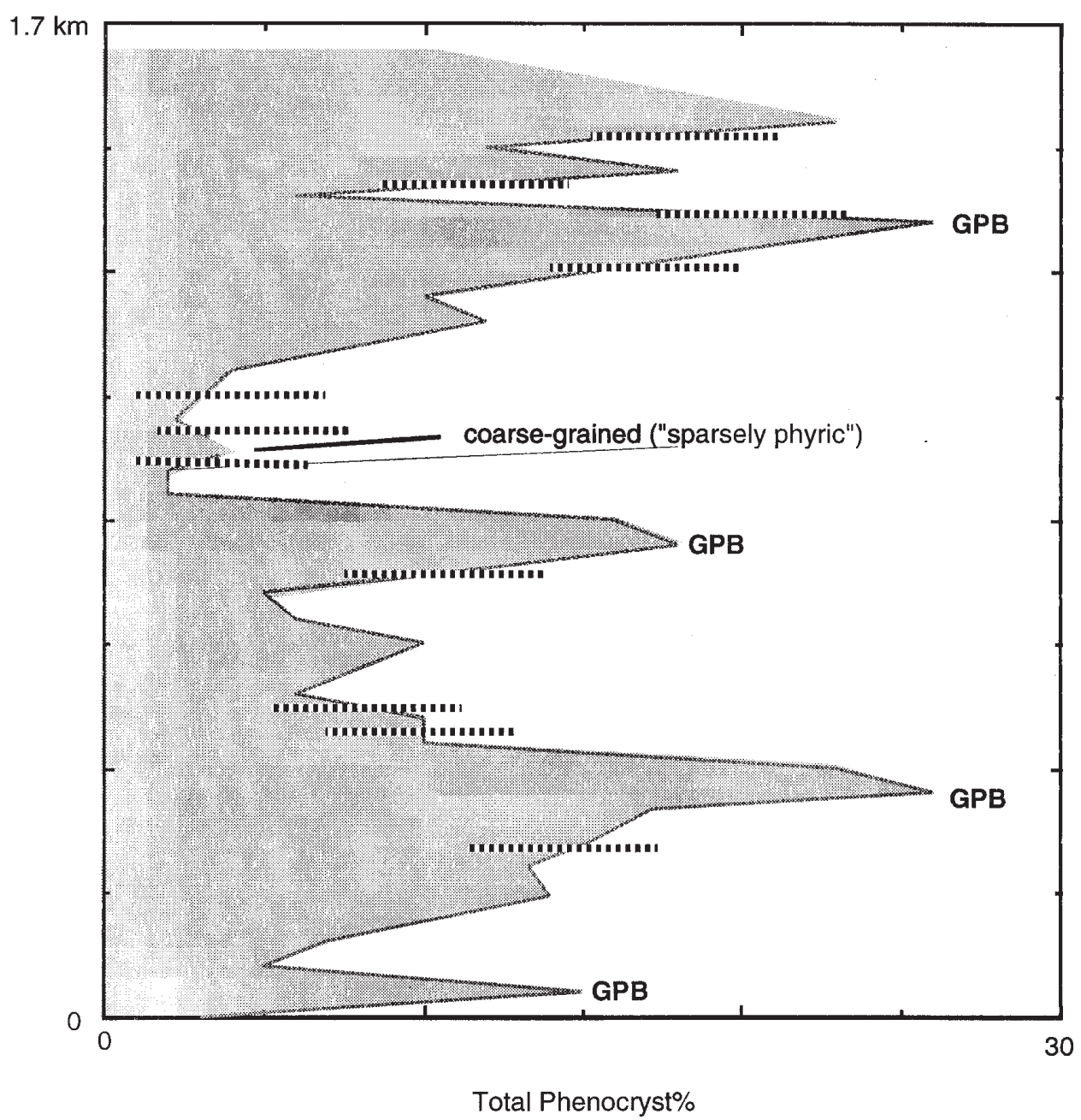

Figure 8. Distribution of Giant Plagioclase Basalt (GPB) lavas and red bole horizons (dotted lines) in the Western Ghats. The shaded area represents variation in total phenocryst\%. (Source: mainly Deshmukh et al 1977, with some input from Beane 1988).

infer that while the red bole (soil) was forming at the surface, the subsurface magma chamber was undergoing a dormant (non-eruptive) phase during which the magma was differentiating and plagioclase crystals in it were growing to large sizes. As mentioned before, GPB eruption perhaps occurred when a new batch of magma entered the magma chamber from below and squeezed the GPB out of the chamber or the chamber itself collapsed. Alternatively, if we accept a pyroclastic origin for the red boles, it would seem that as the giant phenocryts were forming near the roof of the magma chamber (dormancy implied), heat conducted out of the magma chamber and set up convective circulation of groundwater. Such heated fluid may have later been responsible for pyroclastic eruption. Removal of the roof by the pyroclastic eruption would have created the pathway for a GPB eruption.

Irrespective of which of the two alternative interpretations of the red bole horizons we accept, a time gap is implied which would allow the growth of plagioclase phenocrysts to large sizes. In our attempt to have an approximate estimate of this time we assume that these plagioclase crystals were growing continuously (uninterrupted) in a shallow crustal magma chamber (at $\sim 2 \mathrm{kbar}$ ). This is not a bad assumption considering that the giant plagioclase crystals are generally unzoned or weakly zoned (normal zoning) except for their outermost thin rim, which presumably formed in equilibrium with the highly differentiated melts near the roofs of magma chambers. Using some reasonable plagioclase growth-rate data it should be possible to estimate the residence time of such a giant plagioclase crystal in the magma chamber.

Here we use plagioclase growth rate data from a Hawaiian lava lake (Makaopuhi Lava Lake: Cashman and Marsh 1988) and make the assumption that plagioclase crystals in GPBs and Makapuhi grew under similar undercooling rates. Using an approximate growth rate of $9.9 \times 10^{-11} \mathrm{~cm} / \mathrm{sec}$ (Cashman and Marsh 1988) we calculate that it would take about 3200 years for these giant plagioclase crystals to grow to $10 \mathrm{~cm}$ from a small 
nucleus. Accepting that each GPB resided in the magma chamber for that length of time, the six GPBs in figure 8 would account for a total minimum (explained below) time of $6 \times 3200$ or 19,200 years. Based on Beane's data we use a mean thickness of $100 \mathrm{~m}$ for each GPB at the Western Ghats and calculate a one-dimensional eruption rate of $0.031 \mathrm{~m} /$ year. Using this rate, an approximate "back of the envelope" calculated minimum time for the eruption of $1.7 \mathrm{~km}$ of lavas of the Western Ghats is $\sim 55,000$ years.

The time estimated above is likely a minimum number because of the following reasons: (1) There could well be other GPBs that have not been found or are not exposed in the field sections studied. (2) Cohen and Sen (1994) pointed out that Deccan tholeiites underwent fractionation and mixing in relatively shallow $(6 \mathrm{~km})$ chambers. The rate of undercooling in such chambers may have been somewhat slower than that of the Hawaiian lava lake because of the difference in depth. (3) There has been only one detailed study of zoning in individual plagioclase crystals in three GPB flows. $20 \mu \mathrm{m}$ reverse zones within the core regions of crystals and melt inclusions in some cases suggest that dissolution and reprecipitation may have occurred during the formation of some of these plagioclase crystals. Such complexity may translate to a somewhat longer time of residence for the plagioclase crystals. (4) During crystal growth, the rate of growth may not remain a linear function of time because several factors may change. These include the availability of nutrients (proximity to saturation boundary) in the proximity of the crystal surfaces, rate of diffusion, rate of latent heat (released by new growth) dissipation into the melt etc. These factors result in a slower growth rate as the crystal approaches saturation. (5) If indeed the Wai subgroup, which accounts for more than half of the total thickness of the Deccan lavas, does not have a GPB in it as suggested by Hooper (pers. Comm., 2000), then one could propose that, relative to the lower subgroup magmas, the Wai subgroup magmas had a shorter residence time in their magma chambers such that giant phenocrysts did not form (as stated above). In this case, the quoted 55,000.00 years for the entire Western Ghats eruption would be too high a number because it is based on GPB flows.

While the above calculation may have some flaw in details, I believe that the approximate number of 55,000 years for the Western Ghats is still useful because it is a drastically smaller number than the 500,000 years estimated by Courtillot et al (discussed earlier). It is possible that the apparent discrepancy between the time scales estimated from phenocryst growth rate versus paleomagnetic data is either due to the invalidity of one or more assumptions that were made above, or simply reflects the inability of the paleomagnetic time scale to resolve ages $<0.5$ m.y. The time scale obtained from phenocryst growth rate suggests that the duration of the bulk of the Deccan Trap activity could have been significantly shorter than that inferred from paleomagnetic data.

\section{Mineralogy}

\subsection{Olivine}

Olivine in the Deccan is generally altered to a brown iddingsitic material, and can only be recognized by their original crystal form and occurrence as phenocryst. The most magnesian olivines $\left(\mathrm{Fo}_{88-91}\right)$ were discovered in the somewhat unusual basalts in the Dhandhuka borehole in the state of Gujarat (West 1958; Krishnamurthy and Cox 1977). In general, however, it appears that the most magnesian olivines of normal Deccan tholeiite has a $\mathrm{Fo}_{77}$ composition, although $\mathrm{Fo}_{84}$ olivine phenocrysts have been found in Neral and Khandala fomations (cf. Beane 1988; Sen 1980, 1986; Sethna and Sethna 1988). Careful examination of tiny dark brown inclusions in many olivine crystals, particularly in MgO-rich lavas, often revealed that these are chrome-spinels (Sen 1986; Beane 1988; Melluso et al 1995). Plagioclase has also been found to occur as poikilitic inclusion in olivine in the slightly more differentiated lavas. Beane (1988) pointed out that the olivines were generally in equilibrium with the host lavas, although there are clearly proven examples where olivine accumulation has occurred on a local scale

Sen $(1980,1983)$ presented a detailed examination of olivine compositional variations in the famous Chakhla-Delakhari sill in central India. In this sill, compositionally and texturally bimodal olivine occurs throughout the sill. For example, the Upper Chill Zone contains subhedral phenocrysts of olivine $\left(\mathrm{Fo}_{69}\right)$ and Fe-rich skeletal olivine crystals $\left(\mathrm{FO}_{20}\right)$ in the groundmass (Sen 1983).

Recently, Krishnamurthy et al (2000) carried out a detailed examination of olivine in picrite basalts and other basalts of the Deccan in an effort to bracket the composition range of possible primary magmas of the Deccan. Based on bimodal distribution of olivine composition and associated bulk rock elemental composition, these authors classified olivine phenocrysts in Deccan basalts and picrites into two types - Type 1 and Type 2. Cores of Type 1 olivine grains are significantly more forsteritic $\left(\mathrm{Fo}_{86-92}\right)$ than Type-2 olivine phenocrysts $\left(<\mathrm{Fo}_{86}\right)$. Type 1 olivines occur in alkaline-to-transitional lavas in the northwestern 
state of Saurashtra and western SONATA lineament (locations: Ambadongar and Kawant, Pawagarh, Anila and Paliyad, south Kathiawar, and drill holes at Botad, Dhandhuka, and Wadhwan junction). Type 2 olivine is characteristic of the common Deccan tholeiites of the Western Ghats and from other areas.

It is useful to compare the olivine compositions listed above with that of olivines in ultramafic xenoliths that were discovered by De (1964) and analyzed by Krishnamurthy et al (1988). Spinel peridotites, clearly of upper mantle origin, have Fo $_{88-92}$ olivines; and olivines in dunites, which are likely to be of magmatic origin, have $\mathrm{Fo}_{86-92} \mathrm{com}-$ positions. This comparison suggests that primary Deccan magmas probably equilibrated with a mantle that was dominantly peridotitic with "normal" olivine compositions $\left(\mathrm{Fo}_{88-92}\right)$.

\subsection{Plagioclase}

Plagioclase phenocrysts commonly occur in all Deccan basalts with $\mathrm{MgO}<7 \%$ (Beane 1988). Plagioclase phenocryst composition ranges from $\mathrm{An}_{82-61}$, with plagioclase megacrysts in GPB being the most sodic $\left(\mathrm{An}_{64-61}\right.$; see earlier discussion). Based on Sen's (1986) and Beane's (1988) data, it seems that while GPB plagioclases exhibit little zoning (a thin Ab-rich rim is generally present) and a small range in An-content, plagioclase crystals in individual samples of non-GPB lavas exhibit wide variation in An-contents and complicated zoning features. Sen (1986) noted the occurrence of normal and reverse zoned plagioclase in some lavas of the Western Ghats, which he inferred to represent magma mixing. Also, at the Western Ghats, Beane (1988) noticed that the An-content generally correlates well with the $\mathrm{Ca} /(\mathrm{Ca}+\mathrm{Na}+\mathrm{K})$ ratio of the whole rock, suggesting that, in general, the plagioclase crystals were in equilibrium with the host lava. Krishnamurthy and Cox (1977) found extremely calcic plagioclase $\left(\mathrm{An}_{88}\right)$ in the drill hole lavas from northwestern Deccan. However, the maximum calcic plagioclase found by Melluso et al (1995) to be $\mathrm{An}_{82}$ from the lavas in the same general area. Melluso et al applied plagioclase thermometry to calculate eruption temperatures of $1125-1200^{\circ} \mathrm{C}$.

\subsection{Pyroxenes}

Both augite and pigeonite occur in the average Deccan tholeiite (figure 9). Pigeonite is not always easy to detect, and therefore, may seem to be rare (Sethna and Sethna 1988; Beane 1988). In many cases, single pyroxene grains were found to be zoned, with cores of pigeonite and rims of augite (references in Cohen and Sen 1994). Cohen and
Sen thought that in many of the lavas magnesian pigeonite is probably metastable. On the other hand, slightly more Fe-rich pigeonites were thought to have crystallized as a stable phase from the magmas. Sen (1986) calculated $1000-1145^{\circ} \mathrm{C}$ minimum lava temperatures for the Western Ghats based on pigeonite thermometry. A recent experimental study of Bushe lavas has shown that they may have been saturated with a magnesian pigeonite (Gangopadhyay 2000). Pigeonite-fractionation may also be the reason for the Bushe Formation to have a very different fractionation trend than other Deccan lavas (discussed later).

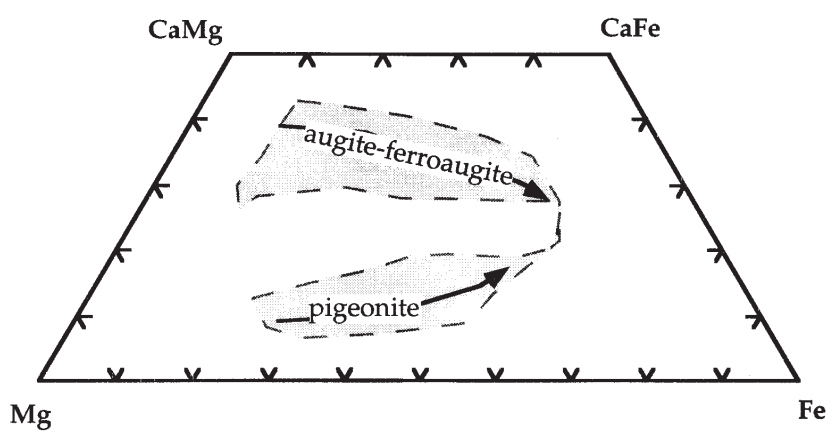

Figure 9. Fields of Deccan pyroxenes. (Data sources: Sen 1980, 1986, 1988; Beane 1988; Sethna and Sethna 1988).

Orthopyroxene is not at all common in the Deccan, although a localized occurrence is clearly related to crustal contamination (Chandrasekharam et al 2000). The general absence or extreme rarity of Ca-poor pyroxene in the Deccan lavas and intrusions is intriguing. Campbell (1985) suggested that one important difference between continental tholeiites and oceanic tholeiities is in the major role of a Ca-poor pyroxene phase in the former and absence (particularly of orthopyroxene) in the latter. He attributed this difference to deep crustal contamination of continental tholeiitic magmas, which forces the magmas to reach the orthopyroxene-saturation surface prior to their further ascent through the shallow crust. One could extend Campbell's argument to the Deccan and suggest that, excluding the Bushe (which does have Ca-poor pyroxene on the liquidus), Deccan lavas did not undergo crustal contamination or the level of contamination was not enough to force orthopyroxene-saturation. Isotope data suggest that with the exception of the bulk of Ambenali, most Deccan lavas are contaminated, and in some cases, strongly contaminated. A plausible explanation of this discrepancy probably lies in extensive magma mixing that these magmas have undergone (e.g., Sen 1986). Efficient magma mixing can keep the mixed magma on the $\mathrm{pl}+\mathrm{aug}+\mathrm{ol}+\mathrm{liq}$ surface even though its isotopic composition (particularly, $\mathrm{Pb}, \mathrm{Sr}, \mathrm{O}$ ) may become dominated by the contaminant. 


\subsection{Other minerals}

The Fe-Ti oxide minerals in the groundmass of Deccan Trap tholeiites are titanomagnetite (sometime partially or wholly altered to maghemite) and ilmenite. These coexisting oxides in the Western Ghats basalts and elsewhere in the Deccan suggest that the groundmass quenched over a temperature range of $1075-975^{\circ} \mathrm{C}$ (cf. Sen 1980; Melluso et al 1995). The $\mathrm{T}-\mathrm{fO}_{2}$ path follows (or closely follows) the QFM buffer curve. Sulfide minerals occur as immiscible globules (De 1974). Rare high temperature sulfides include pyrrhotite and pentlandite; but more commonly it is chalcopyrite or pyrite (De 1974).

\section{Geochemistry and petrogenesis}

The hypothesis that primary Deccan magmas formed by melting of a large plume head is principally based on three principal observations:

- High ${ }^{3} \mathrm{He} /{ }^{4} \mathrm{He}$ ratio of some alkaline intrusive rocks related to the main tholeiitic volcanic episode (Basu et al 1993).

- Large volume of eruption over a relatively short time.

- A hot-spot track that extends from the Deccan to the Chagos-Laccadive islands and the islands of Mauritius and Réunion (with the intermediate complication of post-Deccan sea-floor spreading along the Central Indian and Carlsberg Ridge). Melts produced from the plume head presumably traveled through the continental mantle and crust prior to eruption. The erupted melts thus potentially carry signatures of several sources: continental crust, continental lithospheric mantle, asthenosphere, and the plume. However, identifying the different contributor signals is a difficult task. First, the constraints placed by $\mathrm{Nd}$, Sr, and $\mathrm{Pb}$ isotopic data are discussed. Some discussion of trace element data is interspersed throughout. The major element composition of the Deccan tholeiites is then summarized and its petrogenetic significance discussed.

\subsection{Isotopic signatures}

Isotopic compositions are a useful tool to assess the extent of crustal contamination of mantlederived magmas. Figure 10 shows a plot of $\mathrm{Nd}$ Sr isotopic ratios of some of the western Deccan lava formations (diagram after Peng et al 1994). In this figure, the Ambenali formation lavas $\left(\epsilon_{\mathrm{Nd}}\right.$ of +4 to $+7,{ }^{87} \mathrm{Sr} /{ }^{86} \mathrm{Sr}_{T}$ of $\left.0.7038-0.7044\right)$ represent the least contaminated, end-member composition; and the other formations exhibit different extents of contamination by different components.
Noting that the lower subgroup data array radiate from a "common area" (marked by a star in figure 10), and based on $\mathrm{Pb}$-isotopic and trace element arguments, Peng et al inferred that the "common signature lavas" (i.e., those plotting on or near the star) themselves are plume-derived magmas that were contaminated in the lower crust with high-degree melts ( $40 \%$ partial melts) of Archean amphibolite (Peng et al 1994). These authors considered an alternative suggestion of a continental lithospheric mantle origin of the common signature lavas, but favored crustal contamination because of the high $\delta^{18} \mathrm{O}$ of phenocrysts in the common signature lavas.

According to Peng et al (1994), the three radiating trends exhibited by the lower formation lavas could have resulted from subsequent contamination (i.e., a second stage) involving different crustal components (marked schematically as E1, E2, and E3 in figure 10), possibly Archean amphibolites and granulites, that the lavas came in contact with as they rose through the crust along different pathways.

The Bushe Formation, with its unusually high ${ }^{87} \mathrm{Sr} /{ }^{86} \mathrm{Sr}$ ratios and low ${ }^{143} \mathrm{Nd} /{ }^{144} \mathrm{Nd}$, shows the strongest signature of crustal contamination. This is also borne out by its O-isotopic composition, $\mathrm{Pb}$ isotopic composition and relatively high $\mathrm{SiO}_{2}$ content (Cox and Hawkesworth 1985; Lightfoot et al 1990; Peng et al 1994). However, its relatively high $\mathrm{MgO}$ (as compared to other Deccan formations, e.g., Ambenali) is an interesting puzzle.

The trend shown by the Mahabaleshwar Formation is also interesting. It turns out that Mahabaleshwar lavas reach much lower ${ }^{206} \mathrm{~Pb} /{ }^{204} \mathrm{~Pb}$ values (16.66-17.99) than the Ambenali (17.64-18.24) or Bushe (18.26-22.45: Peng et al 1994). The various hypotheses presented to date to explain this trend are as follows (as reviewed by Peng and Mahoney 1995):

- variable contamination of Ambenali or Reunion type magma by Archean granulites;

- contamination by continental lithospheric mantle;

- Mahabaleshwar lavas are entirely from an Ocean Island Basalt (OIB)-type mantle.

Peng et al rejected the third hypothesis on several grounds, including the lack of any ocean islands with $\mathrm{Pb}$ isotope values as low as those recorded by Mahabaleshwar lavas, and on the basis of $\mathrm{Pb}$ - and $\mathrm{O}$-isotopic data, which clearly show some crustal influence in these lavas.

\subsection{Major element geochemical considerations}

Although Deccan Trap lavas underwent variable degrees of crustal contamination, most of their major element abundances exhibit systematic pat- 
Deccan tholeiites and carbonatites

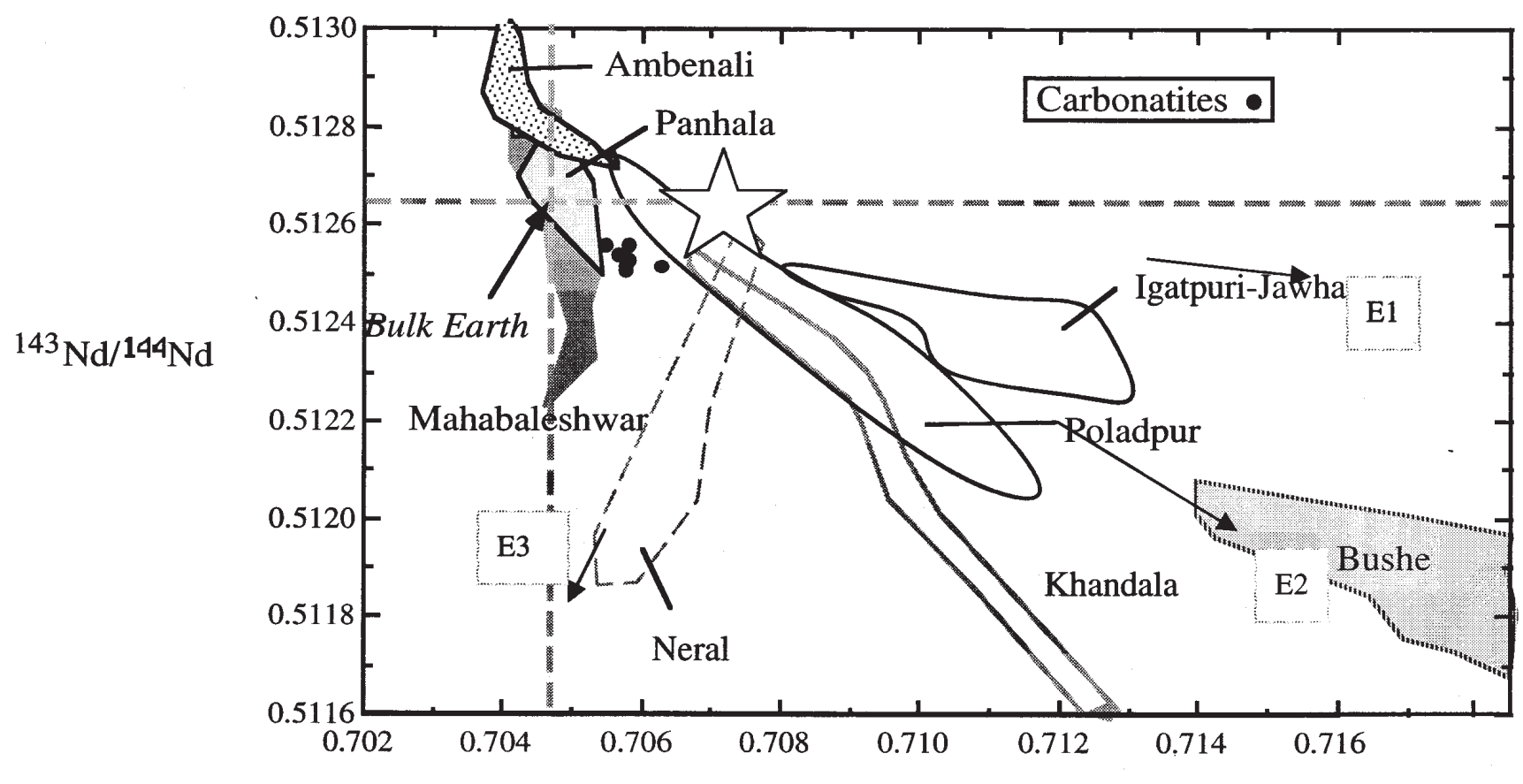

$87 \mathrm{Sr} / 86 \mathrm{Sr}$

Figure 10. Nd-Sr isotopic composition of various tholeiitic lava formations of the Western Ghats compared with that of some Deccan carbonatites. E1, E2, and E3 represent three components that may have affected the Deccan tholeiities. (After Peng et al 1998).

terns that appear to be largely controlled by crystal-liquid fractionation, magma mixing, and partial melting processes (cf. Sen 1995). It further appears that a major control on major element abundances of Deccan basalts in general was fractionation and mixing in shallow $(\sim 2 \mathrm{kbar})$ crustal magma chambers, because they cluster around the 2 kbar pseudocotectic ol $+\mathrm{pl}+\mathrm{cpx}+$ melt (figure 11; Cohen and Sen 1988). Therefore, any attempt to model melting conditions and other, deeper magma ascent processes must first filter out the low-pressure signature.

A somewhat standard approach to "filter out" the low pressure effect is to compare different liquid lines of descent (or differentiation trends) at a comparable level of differentiation. Klein and Langmuir (1987) developed this approach for comparing mid-oceanic ridge basalt trends from different parts of the world at a $\mathrm{MgO}$ value of $8 \%$. This value is significant because primitive MORB glasses or lava have $8 \% \mathrm{MgO}$ and carry only a few per cent olivine phenocrysts. Whether the same approach works for isotopically contaminated basalts of the Deccan is an issue that has been visited by several researchers (e.g., Peng et al 1994; Sen 1995; Turner and Hawkesworth 1995). The general conclusion is that major element composition of these basalts is largely controlled by fractional crystallization and

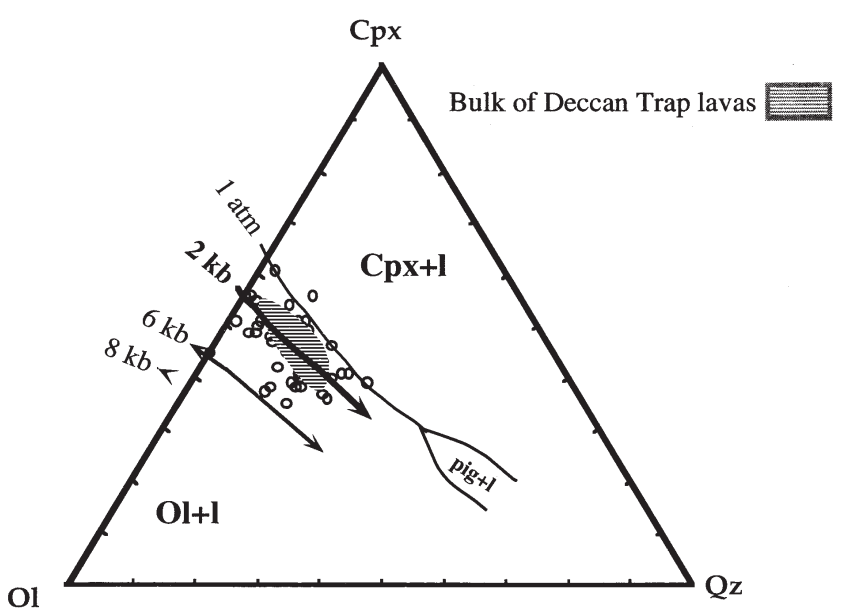

Figure 11. Liquidus projection of Deccan tholeiites (dots and shaded area) compared with ol + pl+aug + l curves at various pressures (After Cohen and Sen 1994).

mixing and very little by contamination (e.g., Cox and Mitchell 1988; Sen 1995). Peng et al (1994) and Turner and Hawkesworth (1995) calculated mean oxide abundances of several western Deccan formations with respect to $8 \% \mathrm{MgO}$. They did the same for Paraná, Siberian Traps, Karoo, and Columbia River Basalts. Based on the available data, some new plots of chemical variations have been made 

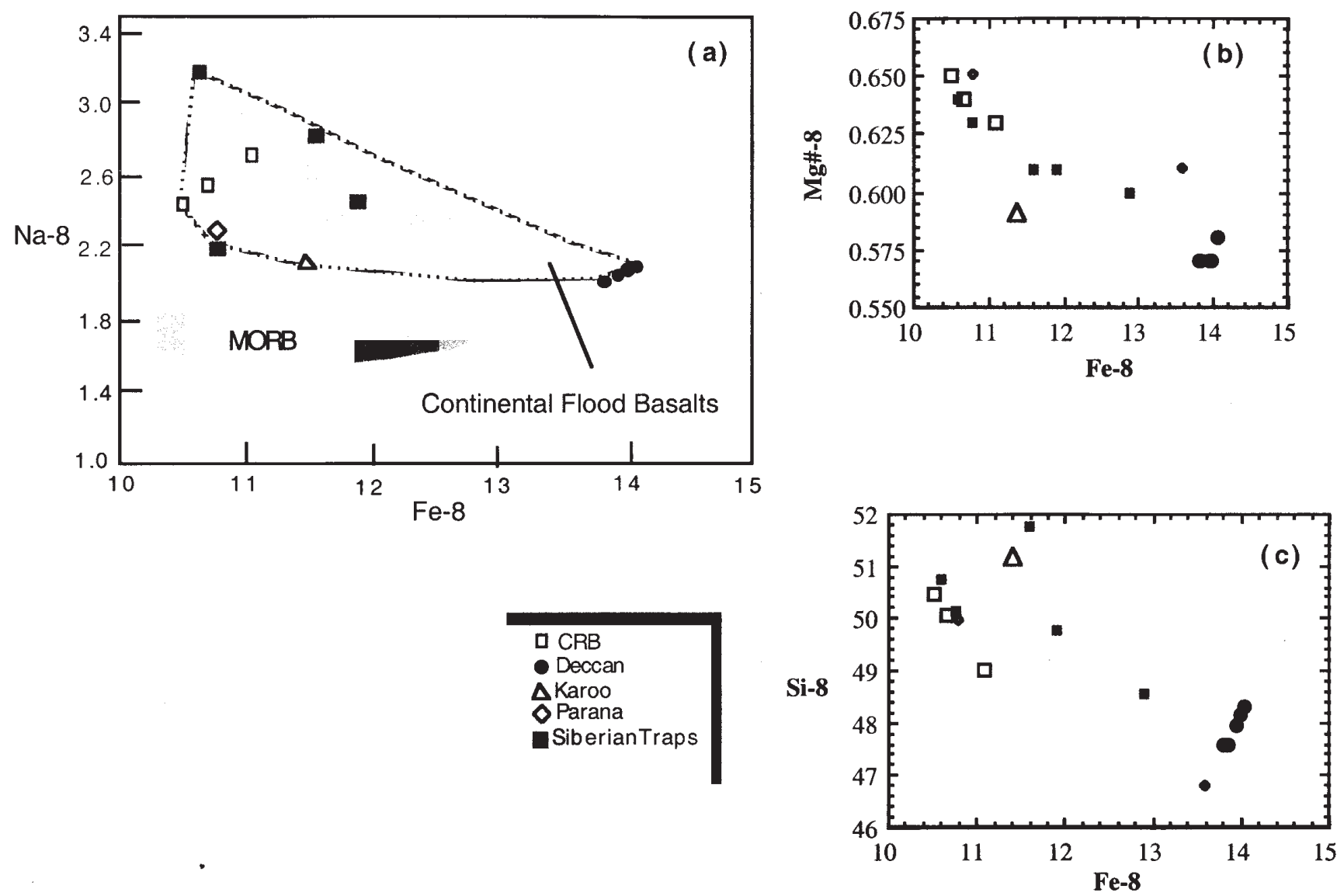

Figure 12. Deccan Trap tholeiites are compared with other flood basalt provinces and MORB on various oxide-oxide plots in which the oxides are normalized to $8 \% \mathrm{MgO}$. (a) Na-8 vs. Fe- 8 plot. Each point refers to $\mathrm{Na}_{2} \mathrm{O}$ and $\mathrm{FeO}{ }^{*}$ values corresponding to $8 \% \mathrm{MgO}$ (see Klein and Langmuir 1987 for the appropriate philosophy and equations). (b) Si-8 vs. Fe- 8 correlation diagram. (c) Fe-8 vs. $\mathrm{Mg} \#$ (i.e., $\mathrm{Mg} /(\mathrm{Mg}+\mathrm{Fe})$ ) correlation diagram. The significance of these plots is discussed in the text.

that expose some interesting aspects of the Deccan basalts (figure 12):

- In terms of $\mathrm{Na}_{8}-\mathrm{Fe}_{8}$ (i.e., $\mathrm{Na}_{2} \mathrm{O}$ and $\mathrm{FeO}^{*}$ at $8 \% \mathrm{MgO})$ Deccan lavas form a tight cluster and define an extreme end member among all continental flood basalt provinces (figure 12a). While other flood basalt provinces broadly overlap the MORB field, the Deccan stands out as distinct from any MORB. Klein and Langmuir (1987) concluded that higher $\mathrm{Fe}_{8}$ reflects greater mean depth of melting (i.e., mean of the entire depth range of melt generation), whereas higher $\mathrm{Na}_{8}$ is an indicator of higher mean percentage of melting of the source (see also, Lassiter and DePaolo 1997). Assuming that the same interpretation holds true (i.e., the source composition remains constant in terms of major elements) for flood basalt provinces, one could argue, based on figure 12(a), that all of Deccan basalts were generated at a mean depth that was greater than other flood basalts and MORB. $\mathrm{Si}_{8}$ (i.e., $\mathrm{SiO}_{2}$ at $8 \% \mathrm{MgO}$ ) variation, which correlates with mean depth of melting, is the greatest in the Deccan (figure 12b). This substantiates the idea that Deccan magmas were generated at a greater mean depth than other flood basalts.

- The $\mathrm{Mg} \#_{8}$ vs. $\mathrm{Fe}_{8}$ (figure 12c) plot shows that the Deccan has the lowest Mg\#. However, this is entirely due to high $\mathrm{FeO}^{*}$ (and not lower $\mathrm{MgO}$, because $\mathrm{MgO}$ values are similar or higher than the others) in the average Deccan basalt relative to averages for the other flood basalt provinces. The implication is that the low $\mathrm{Mg} \#$ in the Deccan is a characteristic inherited during the melting process and was only subsequently enhanced by crystallizationdifferentiation processes.

- The $\mathrm{Nb} / \mathrm{La}$ ratio of the Deccan varies a great deal relative to the other flood basalt provinces, while its $\mathrm{Fe}_{8}$ is essentially constant (figure 13a). I calculated the mean $\mathrm{Nb} / \mathrm{La}$ and $\epsilon_{\mathrm{Nd}}$ of some key Deccan formations and plotted them in figure 13(b). Réunion lavas are also plotted for comparison. Interestingly, the Réunion trend is isotopically virtually invariant and, excluding one anomalous sample, is distinctly higher in $\mathrm{Nb} / \mathrm{La}$ than the bulk earth value and the Deccan. As pointed out by many previous authors 


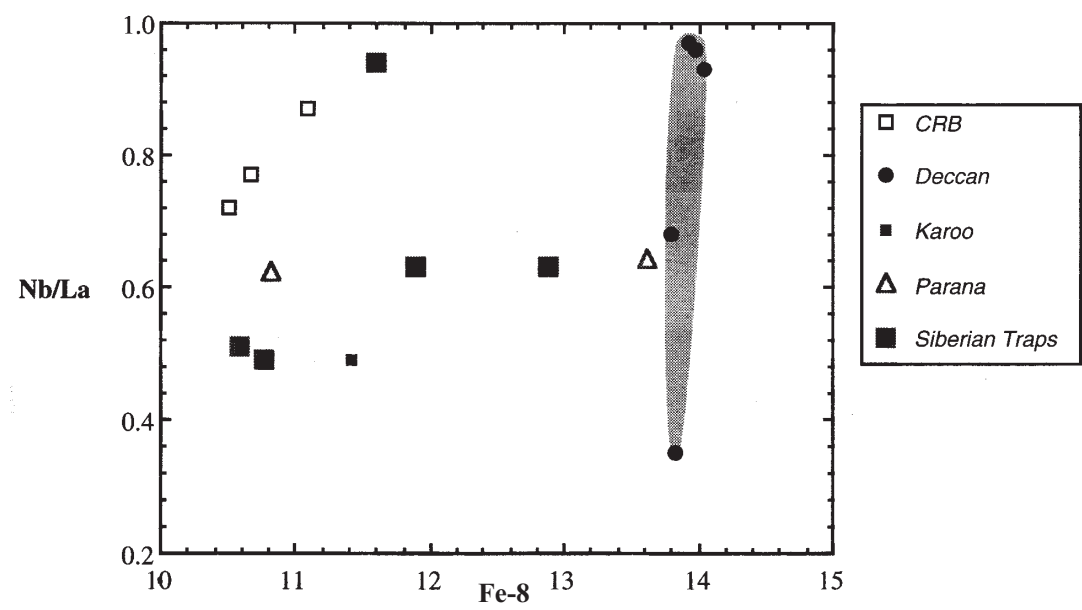

Figure 13(a). Comparison of Nb/La vs. Fe-8 values of the Deccan and other continental LIPs.

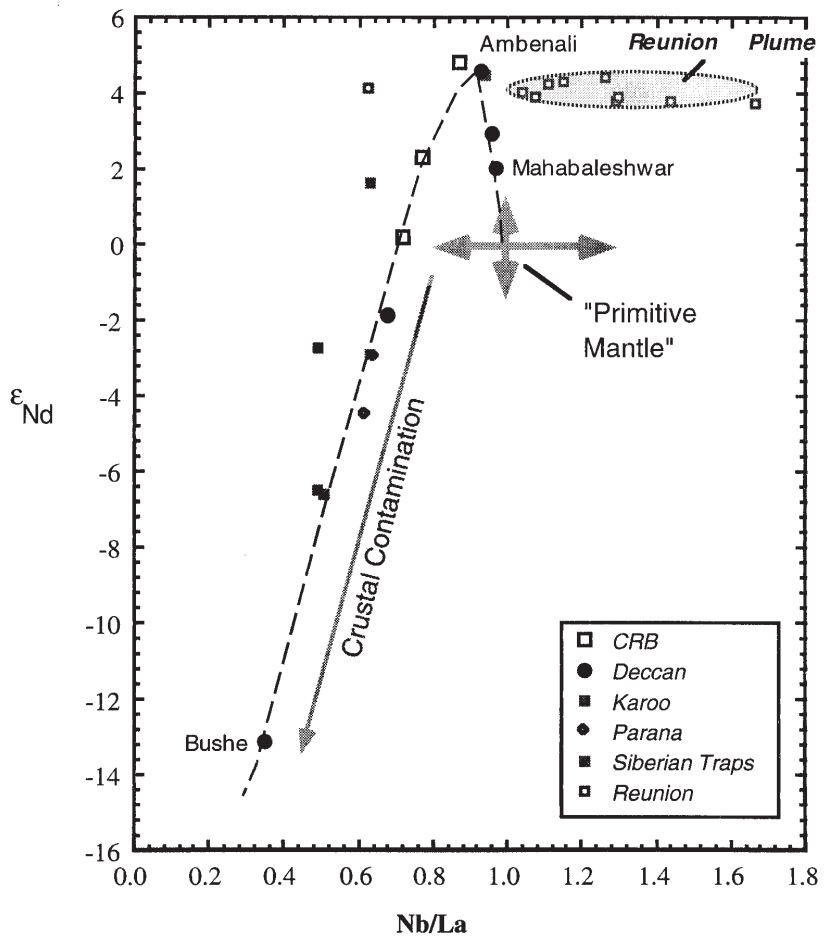

Figure 13(b). Mean values of several Deccan formations, particularly, Ambenali, Mahabaleshwar, and Bushe are compared with that of other continental LIPs, "Bulk Earth" (C1-chondritic) and Reunion basalts (Réunion data: Fisk et al 1988).

(e.g., Peng et al 1994), Ambenali is the closest to the Réunion lavas. In this figure, two separate trends for the Deccan radiate away from the Ambenali- one of which is evidently a trend of crustal contamination (marked by the location of Bushe datum). The other trend, with Mahabaleshwar at its extreme, appears to point toward the primitive mantle (chondritic). One would be tempted to suggest that the Deccan plume tapped a truly primitive mantle layer. However, as discussed earlier, this is ruled out by the isotopic data. The Mahabaleshwar trend was produced by crustal contamination of Réunion-type magma.

\section{Phase equilibria and magma generation}

Simple liquid-line-of-descent (LLD) calculations at 2-10 kbar pressure were performed using a number of parent magmas with a program written by C. Langmuir (Pers. Comm. 1993). One particular parent composition, Amb-2 (47\% $\mathrm{SiO}_{2}, 1.2 \%$ $\mathrm{TiO}_{2}, 13 \% \mathrm{Al}_{2} \mathrm{O}_{3}, 11 \% \mathrm{FeO}^{*}, 16 \% \mathrm{MgO}, 9.6 \% \mathrm{CaO}$, and $1.8 \% \mathrm{Na}_{2} \mathrm{O}$ ), produces a LLD at $2 \mathrm{kbar}$ pressure that approximately fits most oxide variations in the Ambenali Formation lavas (figure 14a,b,c). The only significant exception is $\mathrm{Na}_{2} \mathrm{O}$, which forms a scatter for Ambenali lavas (figure 14d). Bushe Formation trends on these diagrams cannot be fitted by Amb-2 type parent magma. The Bushe trend is likely a result of fractionation of a contaminated magma. In fact, the occurrence of pigeonite on the liquidus of Bushe lavas and $\mathrm{ol}+\mathrm{pl}$ on Ambenali lavas is also suggestive of contamination-influenced differences (Gangopadhyay 2000).

$\mathrm{MgO}-\mathrm{FeO}$ plot (figure 15) shows that the Amb2 starting material (i.e., parent magma) generates a LLD that only touches the Ambenali field; on the other hand, the DeccParent-1 LLD gives a better fit to the Ambenali data. Thus, starting magmas with composition varying between Amb2 and DeccParent-1 provide satisfactory fit to the bulk of Deccan tholeiite fields. Amb-2 is considerably more Fe-rich than all experimentally produced batch partial melts: for example, $32 \%$ melting of the pyrolite source at $\sim 1.5 \mathrm{GPa}(15 \mathrm{kbar})$ produces

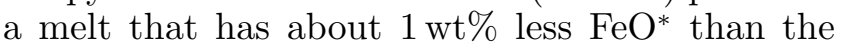
Amb-2 parent melt at a similar $\mathrm{MgO}$ value. Noting 


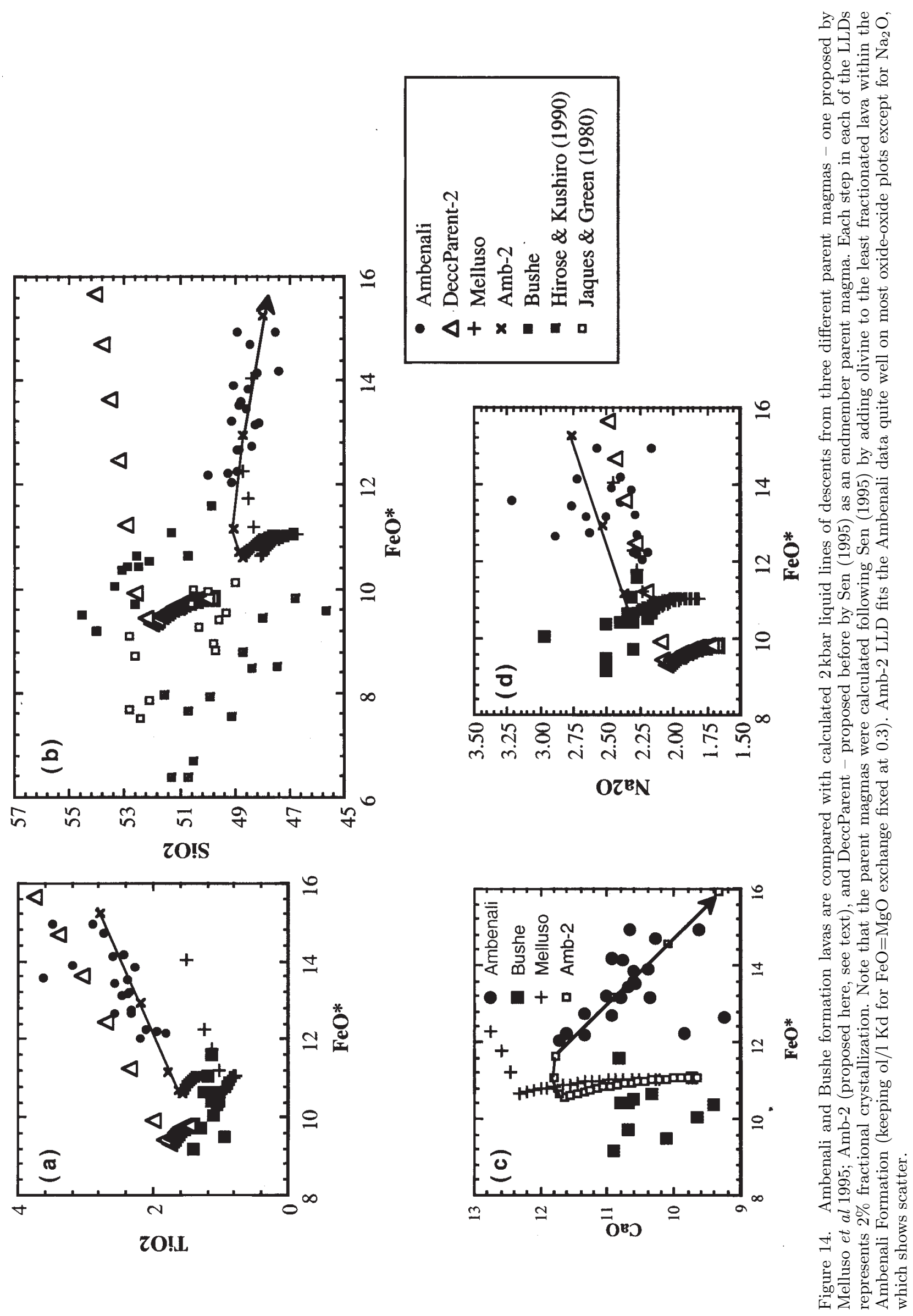



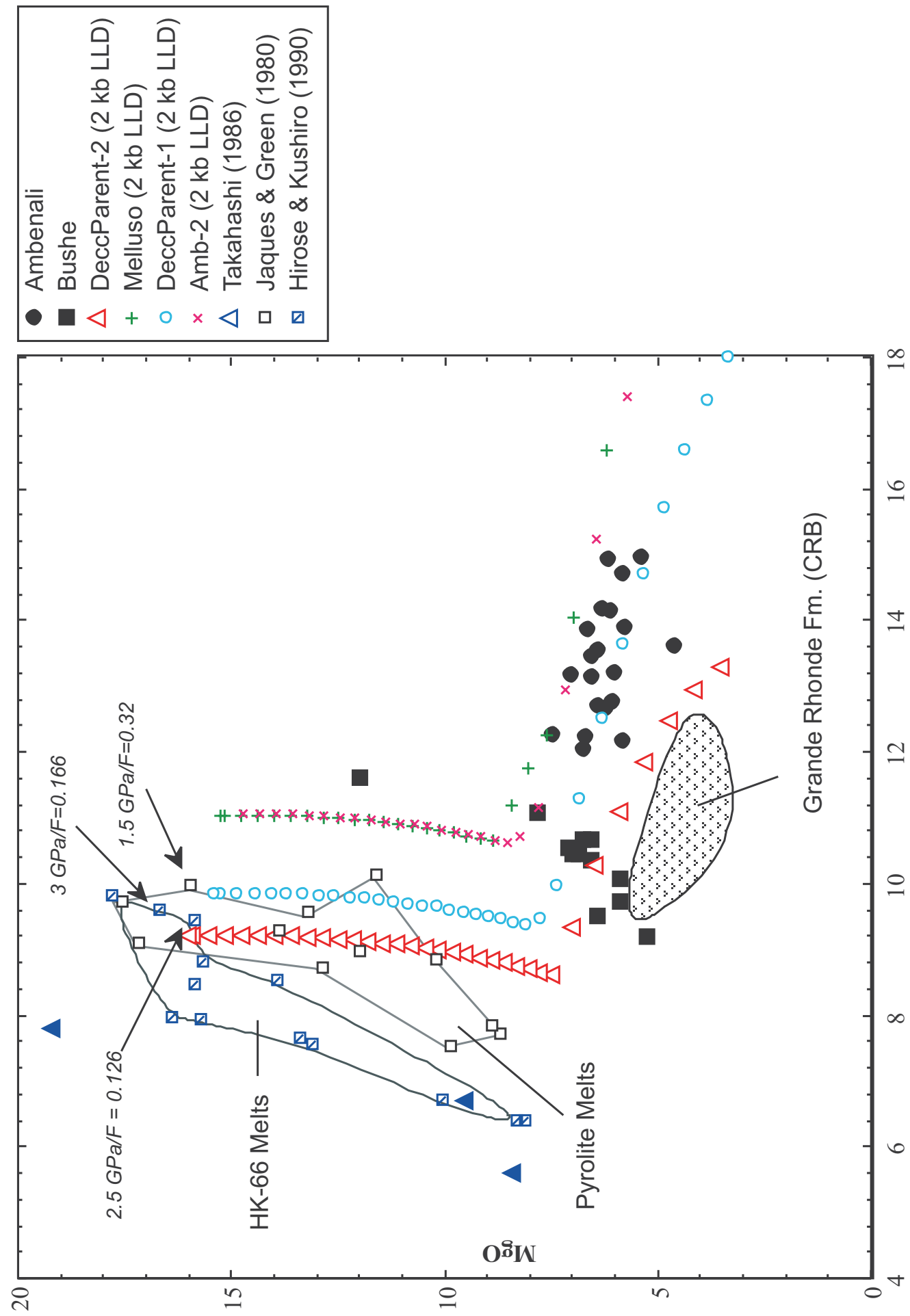

के

L

Ð

ษี శี.

छ

สี กิ हี

पू

$\stackrel{5}{\pi}$

당

त.

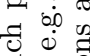

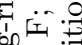

$\sum_{i}^{\infty} \pi$

형

究

च छ

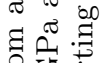

记薷

\pm 용

छ

. స్.

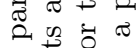

导昰带

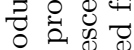

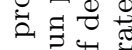

$\Rightarrow$

స్తై

응

预

* $\begin{array}{lll}0 \\ 0\end{array}$

○

ن

:

ठㅇㅇㅇ

ชี

ช $\frac{\pi}{3} \frac{\pi}{3}$

త్తు

우웡

荧 记 西

¿.

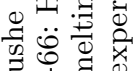

的光

펼.

뜬요

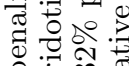

है ڤึ

य न्व

1.

0

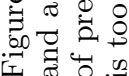


that DeccParent-1 is our best possible candidate for the Ambenali primary magma, and by extension, parent magma of all "common Deccan tholeiites", it is clear that generation of DeccParent-1 type magma would require a more Fe-rich source rock. Prior modeling efforts by White and McKenzie (1995) and Sen (1995), using very different approaches, suggested a mantle potential temperature of $1400^{\circ} \mathrm{C}$ for the Deccan plume and $15-$ $25 \%$ mean melting of the plume. Both authors concluded that melting started around $100 \mathrm{~km}(3 \mathrm{GPa})$ and ended at about $60 \mathrm{~km}(2 \mathrm{GPa})$ below the surface.

\section{Geophysical and petrologic constraints on Deccan magmatism}

A recent re-evaluation of the gravity and seismic data over the Deccan plateau by Pant et al (1999) is of considerable relevance in view of the above summary of petrological assessment of the melting process. Pant et al contrasted studies by previous workers with theirs and came to the following conclusions:

- A density "interface" (i.e., minor discontinuity) occurs at $117 \mathrm{~km}$, which they interpret to be the base of the Indian lithosphere.

- On average, the Moho occurs at $40 \mathrm{~km}$.

- The crust across the SONATA is perhaps trilayered with a (i) lower crust (Vp $=7.2^{-}$ $7.4 \mathrm{~km} / \mathrm{sec}$ ) occurring at $25-40 \mathrm{~km}$, (ii) upper crust $(\mathrm{Vp}=6 \mathrm{~km} / \mathrm{sec})$ of variable thickness between 2 and $12 \mathrm{~km}$; and (iii) middle crust (Vp $=6.9-7.1 \mathrm{~km} / \mathrm{sec}$ (Kaila 1988).

Pant et al felt that the upper crust as defined above is "granitic" crust, and the lower crust is perhaps composed of "underplated" materials without offering any additional explanation.

Sen (1995) calculated that Deccan magmas had lost on average a minimum of $26 \%$ olivine cumulates as they ascended to the mid-crustal "chambers". It is possible that the "lower crust" is composed largely of these dunitic cumulates. The problem is that the observed velocities are perhaps a little too low (should be closer to 8). It is possible that the presence of intercumulus materials in the cumulate-rich lower crust is responsible for driving the $\mathrm{Vp}$ to lower observed values or some preexisting lower Vp crust remains. The "middle crust" is consistent with intrusive complexes where gabbroic fractionation may have occurred prior to the eruption of lavas.

If the petrological inference that plume melting occurred in the $100-60 \mathrm{~km}$ depth range is correct, then comparison with geophysical interpretations leads to the following conclusions:
- The continental lithosphere could have been heavily involved at some point in the melting process; or, alternatively, such lithosphere could have been convectively eroded by magmas and digested back into asthenosphere (a suggestion made by J. Mahoney 2001, pers. comm.)

- The $40-117 \mathrm{~km}$ thick mantle region, which Pant et al call the lithosphere, could very well be partially melted plume residue material that was plated on to the base of the crust. By implication, the $40-117 \mathrm{~km}$ thick mantle region beneath the sub-Deccan crust is very young $(\sim 68-65$ m.y.) is probably mostly plume-derived.

\section{Summary of conclusions}

- The bulk of the Deccan Trap lavas erupted at the $\mathrm{K} / \mathrm{T}$ boundary. Paleomagnetic data suggest $\sim 90 \%$ of the eruption took place in less than 500,000 years. Calculations of the time scale of plagioclase phenocryst growth in giant plagioclase basalts suggest the possibility of a much shorter interval (perhaps as short as 55,000 years) for the eruption of the entire package of Western Ghats basalts (the type section).

- The main center of eruption appears to be an area near Nasik. There were other centers as well, most notably, one in the Satpura region of Central India, one in the northwest in the Cambay area, and a few more along the SONATA lineament.

- The bulk of the lavas are tholeiitic with $<7 \%$ $\mathrm{MgO}$ and carry phenocrysts of olivine and plagioclase. Many also contain augite phenocrysts. Pigeonite phenocrysts are rare but its relative abundance in the groundmass is a topic of debate. Aside from the tholeiites, carbonatites and other mafic alkaline lavas also occur in minor amounts. Mantle xenoliths, mostly spinel lherzolites and pyroxenites, have been found in some intrusions and lavas on the west coast.

- The Deccan Traps of the type area have been divided into eleven formations based on geochemistry, among which the most definitive are the Ambenali, Poladpur, and Bushe formations. Bushe lavas show the strongest signatures of contamination by the continental crust. The Ambenali is the thickest formation and is the least contaminated. The Poladpur may be laterally the most extensive among all formations.

- Comparison between the Deccan and other continental flood basalt provinces in terms of $\mathrm{Na}_{8}$, $\mathrm{Fe}_{8}$ and $\mathrm{Si}_{8}$ (where the subscript 8 stands for data at $8 \% \mathrm{MgO}$ ) indicates that the Deccan magmas were produced by the greatest degree of melting and at a depth range greater than 
the other flood basalts. These melts underwent olivine-fractionation near the Moho and then further gabbroic fractionation within the shallow-intermediate crust $(6 \mathrm{~km}$ below the surface; $\sim 2$ kbar pressure). Quantitative modeling suggests that the melting range may have been $100-60 \mathrm{~km}$ below the surface. This depth range would suggest that the continental lithosphere was involved in the melting and contamination process; and the present mantle portion of the Indian lithosphere may have a large component of plume residues "plated" onto the base.

\section{Acknowledgement}

This paper is my humble tribute to Sisirda, who has been an inspiration to all of us. I also dedicate this to Professor Aniruddha De, who started me on the Deccan Traps many years ago. I thank Prof. J. Ganguly for his thoughtful remarks and for his invitation to write this paper. I am particularly grateful to Profs. P Hooper, J Mahoney, S Chakraborty, D Chandrasekharam, and an anonymous reviewer for their comments.

\section{References}

Allegre C J, Birck J L, Capmas F and Courtillot V 1999 Age of the Deccan Traps using ${ }^{187} \mathrm{Re}^{187}$ Os systematics; Earth Planet. Sci. Lett. 170 197-204

Baksi A K 1994 Geochronological studies on whole-rock basalts, Deccan Traps: evaluation of the timing of volcanism relative to the K-T boundary; Earth Planet. Sci. Lett. $12143-56$

Basu A R, Renne P R, Dasgupta D K, Teichmann F and Poreda R J 1993 Early and late alkali igneous pulses and a high- ${ }^{3} \mathrm{He}$ plume origin for the Deccan flood basalts; Science 261 902-906

Beane J E 1988 Flow stratigraphy, chemical variation and petrogenesis of Deccan flood basalts, Western Ghats, India, Ph.D. Dissertation, Washington State University, Pullman, 576p.

Beane J E and Hooper P R 1988 A note on the picrite basalts of the Western Ghats, Deccan Traps, India; Mem. Geol. Soc. India 10 117-133

Beane J E, Turner C A, Hooper P R, Subbarao K V and Walsh J N 1986 Stratigraphy, composition and form of the Deccan basalts, Western Ghats, India; Bull. Volcanol. 48 61-83

Bhattacharji S, Chatterjee N, Wampler J M and Gazi M 1994 Mafic dikes in Deccan volcanics - indicator of India intraplate rifting, crustal extension and Deccan flood basalt volcanism. In: Volcanism, ed. K V Subbarao Geol. Soc. India 253-276

Bose M K 1980 Alkaline magmatism in the Deccan volcanic province; J. Geol. Soc. India 21 317-329

Campbell I H 1985 The difference between oceanic and continental tholeiites: a fluid dynamic explanation; Contrib. Mineral. Petrol. 20 244-267

Campbell I H and Griffiths R W 1990 Implications of mantle plume structure for the evolution of flood basalts; Earth Planet. Sci. Lett. 99 79-93
Cashman K V and Marsh B D 1988 Crystal size distribution, CSD, in rocks and the kinetics and dynamics of crystallization. III. Makaopuhi lava lake;Contrib. Mineral. Petrol. 99 292-305

Chandrasekharam D, Vasselli O, Sheth H C and Keshav S 2000 Petrogenetic significance of ferro-enstatite orthopyroxene in basaltic dikes from the Tapi rift, Deccan flood basalt province, India; Earth Planet. Sci. Lett. 179 469476

Chatterjee S and Rudra D K 1992 KT events in India: impact, rifting, volcanism and dinosaur extinction; $\mathrm{Mem}$ oir of the Queensland Museum 39 489-532

Coffin M F and Eldholm O 1993 Large igneous provinces; Sci. Am. 269 42-49

Cohen T H and Sen G 1994 Fractionation and ascent of Deccan Trap magmas: An experimental study at 6 kilobar pressure; In Volcanism (ed) K V Subbarao, Geol. Soc. India $173-186$

Courtillot V, Besse J, Vandamme D, Montigny R, Jaeger J J and Capetta H. 1986 Deccan flood basalts at the Cretaceous/ Tertiary boundary; Earth Planet. Sci. Lett. 80 361374

Cox K G and Mitchell C 1988 Importance of crystal settling in the differentiation of Deccan Trap basaltic magmas; Nature 333 447-449

Cox K G and Hawkesworth C J 1985 Geochemical stratigraphy of the Deccan Traps at Mahabaleshwar, Western Ghats, India, with implications for open system magmatic processes; J. Petrol. 26 355-377

Cox K G 1999 The role of mantle plumes in the development of continental drainage patterns. In: Deccan Volcanic Province, (ed.) K. V. Subbarao Mem. Geol. Soc. India 43 607-618

Crookshank H 1936 Geology of the northern slopes of the Satpuras between the Morand and Sher rivers; Geol. Surv. India Mem. 66

De A 1964 Iron-titanium oxides and silicate minerals of the alkali olivine basalts, tholeiites and acidic rocks of the Deccan Trap series and their significance. Int. geol. Congress Report $22^{\text {nd }}$ Session, Pt III, 126 New Delhi

De A 1974 Silicate liquid immiscibility in the Deccan Traps and its petrogenetic significance; Bull.Geol. Soc. Am. 85 471-474

Deshmukh S S, Aramaki S, Shimizu N, Kurasawa N and Konda T 1977 Petrography of the basalt flows exposed along Mahabaleshwar and Amboli sections in Western Ghats, India; Geol. Surv. India, Rec. 108 81-103

Dessai A G and Vaselli O 1999 Petrology and geochemistry of xenoliths in lamprophyres from the Deccan Traps: implications for the nature of the deep crust boundary in western India Mineralogical Magazine 63 703-708

Devey C W and Cox K G 1987 Relationships between crustal contamination and crystallization in continental flood basalt magmas with special reference to the Deccan Traps of Western India; Earth Planet. Sci. Lett. 84 59-68

Duncan R A and Pyle D G 1988 Rapid eruption of the Deccan flood basalts at the Cretaceous/Tertiary boundary; Nature 333 841-843

Duncan R A and Richards M A 1991 Hotspots, mantle plumes, flood basalts, and true polar wander; Rev. Geophys. 29 31-50

Fisk M R, Upton B G J, Ford C E and White W M 1988 Geochemical and experimental study of the genesis of magmas of Reunion island, Indian Ocean; J. Geophys. Res. 93 4933-4950

Gangopadhyay A 2000 An experimental petrologic study of basalts from selected formations of the Deccan Traps, India; M.S. Thesis, Florida International University, 105p 
Griffiths R W and Campbell I H 1990 Stirring and structure in mantle plumes; Earth Planet. Sci. Lett. 99 66-78

Griffiths R W and Campbell I H 1991a On the dynamics of long-lived plume conduits in the convecting mantle; Earth Planet. Sci. Lett. 103 214-227

Griffiths R W and Campbell I H 1991b Interaction of mantle plume heads with the Earth's surface and onset of smallscale convection; J. Geophys. Res. 96 18295-18310

Gupte R B 1995 Comments on the research note "On the origin of bole beds in Deccan Traps" by P M Inamdar and D Kumar; J. Geol. Soc. India 45 607-608

Gwalani L, Rock N M S, Chang W-J and Fernandez F 1993 Alkaline rocks and carbonatites of Amba Dongar and adjacent areas, Deccan Igneous Province, Gujarat, India. 1. Geology, petrography, and Petrochemistry; Mineral. Petrol. 47 219-253

Gwalani L G and others 1995 Alkaline and tholeiitic dyke swarm associated with Amba Dongar and Phenai Mata complexes, Chhota Udaipur alkaline sub-province, western India; J. Geol. Soc. India Mem 33 391-423

Hirose K and Kushiro I 1993 Partial melting of dry peridotites at high pressures: Determination of compositions of melts segregated from peridotite using aggregates of diamond; Earth Planet. Sci. Lett. 114 477-489

Hooper P and others 1988 The Giant Plagioclase Basalts (GPBs) of the Western Ghats, Deccan Traps; Mem. Geol. Soc. India 10 135-144

Hooper P R 1999 The winds of change, The Deccan Traps: A personal perspective. In: Deccan Volcanic Province (ed.) K V Subbarao Mem. Geol. Soc. India 43 153-165

Inamdar P M and Kumar D 1994 On the origin of bole beds in Deccan Traps; J. Geol. Soc. India 44 331-334

Inamdar P 1995 Reply to comments by R B Gupte: J. Geol. Soc. India 45, 608-609

Jaques A L and Green D H 1980 Anhydrous partial melting of peridotite at $0-15 \mathrm{~kb}$ pressure and the genesis of tholeiitic basalts; Contrib. Mineral. Petrol. 73 287-310

Kaila K L 1988 Mapping the thickness of Deccan Trap flows in India from DSS studies and inferences about a hidden Mesozoic basin in the Narmada-Tapti region. In: Deccan Flood Basalts (ed.) K. V. Subbarao Mem. Geol. Soc. India 10 91-116

Kellogg L H, Hager B H and van der Hilst R D 1999 Compositional stratification in the deep mantle; Science $\mathbf{2 8 3}$ 1881-1884

Khadri S F R, Subbarao K V and Walsh J N 1999 Stratigraphy, form, and structure of the East Pune basalts, western Deccan Basalt province, India. In: Deccan Volcanism (ed.) K. V. Subbarao Mem., Geol. Soc. India 43 179-202

Klein E and Langmuir C H 1987 Global correlations of ocean ridge basalt chemistry with axial depth and crustal thickness; J. Geophys. Res. 92 8089-80115

Krishnamurthy P and Cox K G 1977 Picrite basalts and related lavas from the Deccan Traps of western India; Contrib. Mineral. Petrol. 62 53-75

Krishnamurthy P, Pande K, Gopalan K and Macdougall J D 1988 Upper mantle xenoliths in alkali basalts related to Deccan Trap volcanism. In Deccan Flood Basalts, (ed.) K. V. Subbarao Geol. Soc. India Mem. 10 53-67

Krishnamurthy P, Gopalan K and Macdougall J D 2000 Olivine compositions in picrite basalts and the Deccan volcanic cycle; J. Petrol. 41 1057-1069

Krishnan M S 1982 Geology of India and Burma, 6th edition, (Delhi.: CBS Publishers and Distributors).

Lassiter J C and DePaolo D J 1997 Plume/lithosphere interactions in the genesis of continental and oceanic flood basalts: chemical and isotopic constraints; In Large igneous provinces: continental, oceanic, and planetary flood volcanism; (eds) J J Mahoney and M F Coffin; Am. Geophys. Union Monograph 100 335-356

Lightfoot P C, Hawkesworth C J, Devey C W, Rogers N W and van Calsteren P W C 1990 Source and differentiation of Deccan Trap lavas: implications of geochemical and mineral chemical variations; J. Petrol. 31 1165-1200

Mahadevan T M and Subbarao K V 1999 Seismicity of the Deccan volcanic province-an evaluation of some endogenous factors. In: Deccan Volcanism, (ed.) K V Subbarao, Mem. Geol. Soc. India 43 453-484

Mahoney J and others 1982 Origin of the Deccan Trap flows at Mahabaleshwar inferred from $\mathrm{Nd}$ and $\mathrm{Sr}$ isotopic and chemical evidence; Earth Planet. Sci. Lett. 60 47-60

Mahoney J J 1988 Deccan Traps. In: Continental flood basalts, (ed) Macdougall J D (Dordrecht: KluwerAcademic), pp 151-194

Mahoney J, Macdougall J D, Lugmair G W, Gopalan K and Krishnamurthy P 1985 Origin of contemporaneous tholeiite and K-rich alkalic lavas: a case study from the Northern Deccan plateau; Earth Planet. Sci. Lett. 73 3953

Mahoney J, Sheth H C, Chandasekharam D and Peng Z X 2000 Geochemistry of flood basalts of the Toranmal section, Northern Deccan Traps, India: implications for regional Deccan stratigraphy; J. Petrol. 41 1099-1120

McLean D M 1985 Deccan Trap mantle degassing in the terminal Cretaceous marine extinctions; Cretaceous Research 6 235-259

Melluso L L, Beccaluva R, Brotzu A, Gregnanin A, Gupta K, Morbidelli L and Traversa G G 1995 Constraints on the mantle sources of the Deccan Traps from the petrology and geochemistry of Basalts of Gujarat state, western India; J. Petrol. 36 1393-1432

Mitchell C H and Widdowson M 1991 A geological map of the southern Deccan Traps, India and its structural implications; J. Geol. Soc. London 148 495-505

Najafi S, Cox K G and Sukeshwala R N 1981 Geology and geochemistry of the basalt flows, Deccan Traps, of the Mahad-Mahabaleshwar section, India; In: Volcanism and related provinces in other parts of the world, (eds.) K V Subbarao and R N Sukeshwala; Mem. Geol. Soc. India 3 300-315

Pankov V and others 1994 Mineral and melt inclusions in the Giant Plagioclase phenocrysts of Deccan Basalts, Western Ghats, India: Some comparisons with plagioclases of intrusive Siberian Traps and implications on the physicochemical conditions during magmatic evolution; In: Volcanism, (ed) K V Subbarao, Geol. Soc. India 187-199

Pant P R and others 1999 Significant inferences on deep crustal structure of Deccan Trap region from spectral analyses of Bouguer anomalies; J. Geol. Soc. India 53 315-328

Peng Z X and others 1994 A role for lower continental crust in flood basalt genesis? Isotopic and incompatible element study of the lower six formations of the western Deccan Traps; Geochim. Cosmochim. Acta 58 267-288

Peng Z X and Mahoney J J 1995 Drillhole lavas from the northwestern Deccan Traps, and the evolution of the Reunion hotspot mantle; Earth Planet. Sci. Lett. 134 169-185

Peng Z X and others 1998 Basalts of the northeastern Deccan Traps, India: isotopic and elemental geochemistry and relation to southwestern Deccan Trap stratigraphy; J. Geophys. Res. 103 29843-29865

Ravi Shanker 1988 Heat flow map of India and its geological and economic significance; Indian Mineral. 42 89-110

Ray J S,. Trivedi J R and Dayal A M 2000 Strontium isotope systematics of Amba Dongar and Sung Valley carbonatitealkaline complexes, India: evidence for liquid immiscibil- 
ity, crustal contamination and long-lived $\mathrm{Rb} / \mathrm{Sr}$ enriched mantle sources; J. Asian Earth Sci. 18 585-594

Richards M A, Duncan R A and Courtillot V E 1989 Flood basalts and hot spot tracks: Plume heads and tails; Science 246 103-107

Sen G 1980 Mineralogical variations in the Delakhari Sill, Deccan Trap intrusion, Central India; Contrib. Mineral. Petrol. 75 71-78

Sen G 1983 Deccan Trap intrusion: Magma mixing in the Chakhla-Delakhari sill, Chhindwara district, Madhya Pradesh; J. Geol. Soc. India 24 381-393

Sen G 1986 Mineralogy and petrogenesis of the Deccan Trap lava flows around Mahabaleshwar, India; J. Petrol. 27 627-663

Sen G 1988 Possible depth of origin of primary Deccan tholeiite magma; Mem. Geol. Soc. India 10 34-51

Sen G and Cohen T H 1994 Deccan intrusion, crustal extension, doming and the size of the Deccan-Reunion plume head; In Volcanism, (ed) K V Subbarao, Geol. Soc. India 201-216

Sen G 1995 A simple petrologic model for the generation of Deccan Trap magmas; Int. Geol. Rev. 37 825-850

Sen G 2001 Earth's Materials: Minerals and Rocks (Upper Saddle River, N.J., Prentice-Hall), 542 pp

Sethna S F and Sethna B S 1988 Mineralogy and petrogenesis of Deccan Trap basalts from Mahabaleshwar, Igatpuri, Sagar, and Nagpur areas, India. In: Deccan Flood Basalts, (ed) K V Subbarao, Mem. Geol. Soc. India 10 69-90

Sethna S F and Mousavi M 1994 Geology and petrochemistry of Deccan Traps along a part of the western coastal tract. In: Volcanism, (ed) K V Subbarao 233-252

Sheth H C 1999 A historical approach to continental flood basalt volcanism: insights into pre-volcanic rifting, sedimentation, and early alkaline magmatism; Earth Planet. Sci. Lett. 168 19-26

Simonetti A, Bell K and Viladkar S G 1995 Isotopic data from the Amba Dongar carbonatite complex, west-central India: evidence for an enriched mantle source; Chem. Geol. 122 185-198

Subbarao K V and Hooper P R 1988 Reconnaissance map of the Deccan Basalt Group in the Western Ghats, India; In: Deccan Flood Basalts, (ed) K V Subbarao, Mem. Geol. Soc. India 10
Subbarao K V and others 1994 Stratigraphy and structure of parts of the central Deccan basalt province: eruptive models; In Volcanism, (ed) K V Subbarao, Geol. Soc. India $321-332$

Sukheswala R N and Poldervaart A 1958 Deccan basalts of the Bombay area, India: Bull. Geol. Soc. Am. 69 14751494

Takin M 1966 An interpretation of the positive gravity anomaly over Bombay on the west coast of India; J. Astr. Soc. Geophys. Suppl. 11 527-533

Turner S and Hawkesworth C 1995 The nature of subcontinental mantle: constraints from the major-element composition of continental flood basalts; Chem. Geol. $120295-314$

Venkatesan T R, Pande K and Gopalan G 1993 Did Deccan volcanism pre-date the Cretaceous/Tertiary transition? Earth Planet. Sci. Lett. 119 181-189

Walker G P L 1999 Some observations and interpretations on the Deccan Traps; In: Deccan Volcanic Province, (ed) K V Subbarao, Mem. Geol. Soc India 43 367-395

Watson E B 1982 Basalt contamination by continental crust: some experiments and models; Contrib. Mineral. Petrol. $8073-87$

Watts A B and Cox K G 1989 The Deccan Traps: an interpretation in terms of progressive flexure in response to a migrating load; Earth Planet. Sci. Lett. 93 85-97

West W D 1958 The petrography and petrogenesis of fortyeight flows of Deccan Traps penetrated by borings in western India; Trans. Nat. Inst. Sci. India 4 1-56

West W D 1981 The duration of Deccan Trap volcanicity; Mem. Geol. Soc. India 3 277-278

White R S and McKenzie D 1995 Mantle plumes and flood basalts; J. Geophys. Res. 100 17543-17585

Widdowson M and Mitchell C 1999 Large-scale stratigraphical, structural, and geomorphological constraints for earthquakes in the southern Deccan Traps, India: the case for denudationally-driven seismicity; Mem. Geol. Soc. India 43 425-452

Wilkins A, Subbarao K V, Ingram G and Walsh J N 1994 Weathering regimes within Deccan basalts. In: Volcanism, (ed) K V Subbarao, (New Delhi: Wiley Eastern) $217-231$

Wilson M 1989 Igneous Petrogenesis, (London: Unwin Hyman). 